\title{
Dopamine and Risk Choices in Different Domains: Findings Among Serious Tournament Bridge Players
}

\section{Citation}

Dreber-Almenberg, Anna, David Gertler Rand, Nils Christian Wernerfelt, Justin R. Garcia, J. Koji Lum, and Richard Jay Zeckhauser. 2010. Dopamine and Risk Choices in Different Domains: Findings among Serious Tournament Bridge Players. Faculty Research Working Paper Series, RWP10-034, Harvard Kennedy School, Harvard University.

\section{Published Version}

http://web.hks.harvard.edu/publications/getFile.aspx?ld=587

\section{Permanent link}

http://nrs.harvard.edu/urn-3:HUL.InstRepos:23936103

\section{Terms of Use}

This article was downloaded from Harvard University's DASH repository, and is made available under the terms and conditions applicable to Other Posted Material, as set forth at http:// nrs.harvard.edu/urn-3:HUL.InstRepos:dash.current.terms-of-use\#LAA

\section{Share Your Story}

The Harvard community has made this article openly available.

Please share how this access benefits you. Submit a story.

Accessibility 


\section{Dopamine and Risk Choices in}

Different Domains: Findings Among

Serious Tournament Bridge Players

Faculty Research Working Paper Series

\section{Anna Dreber}

Harvard Kennedy School

David G. Rand

Harvard University

Nils Wernerfelt

Harvard Kennedy School

J ustin R. Garcia

Binghamton University

J. Koji Lum

Binghamton University

Richard Zeckhauser

Harvard Kennedy School

\section{J uly 2010}

\section{RWP10-034}

\footnotetext{
The views expressed in the HKS Faculty Research Working Paper Series are those of the author(s) and do not necessarily reflect those of the John F. Kennedy School of Government or of Harvard University. Faculty Research Working Papers have not undergone formal review and approval. Such papers are included in this series to elicit feedback and to encourage debate on important public policy challenges. Copyright belongs to the author(s). Papers may be downloaded for personal use only.
} 


\title{
Dopamine and Risk Choices in Different Domains: Findings Among Serious Tournament Bridge Players
}

\author{
Anna Dreber ${ }^{1,2}$, David G. Rand ${ }^{3,4,5}$, Nils Wernerfelt ${ }^{6,7}$, Justin R. Garcia ${ }^{8}$, J. Koji Lum ${ }^{8}$ \& \\ Richard Zeckhauser ${ }^{6 \S}$
}

${ }^{1}$ Institute for Financial Research (SIFR), Drottninggatan 89, 11360 Stockholm, Sweden; ${ }^{2}$ Women and Public Policy Program, Harvard Kennedy School, 79 John F. Kennedy Street, Cambridge, MA 02138, USA; ${ }^{3}$ Program for Evolutionary Dynamics, Harvard University, 1 Brattle Square, ste 6, Cambridge, MA 02138, USA; ${ }^{4}$ Berkman Center for Internet and Society, Harvard University, 23 Everett Street, Cambridge, MA 02138, USA. ${ }^{5}$ Department of Psychology, Harvard University, 33 Kirkland Street, Cambridge, MA 02138, USA. ${ }^{6}$ Kennedy School of Government, Harvard University, 79 John F. Kennedy Street, Cambridge, MA 02138, USA; ${ }^{7}$ Toulouse School of Economics, Manufacture de Tabacs, 21 allées de Brienne 31000 Toulouse, France; ${ }^{8}$ Laboratory of Evolutionary Anthropology and Health, Departments of Biological Sciences and Anthropology, Binghamton University, PO Box 6000, Binghamton, New York 13902, USA.

${ }^{\S}$ To whom correspondence should be addressed: John F. Kennedy School of Government, Mailbox 41, 79 John F. Kennedy Street, Cambridge, MA 02138, USA. Phone: 617-495-1174, Fax: 617-384-9340, Email: richard_zeckhauser@harvard.edu.

\begin{abstract}
Individuals differ significantly in their willingness to take risks, partly due to genetic differences. We explore how risk taking behavior correlates with different versions of the dopamine receptor D4 gene (DRD4). We focus on risk taking in the card game contract bridge, and economic risk taking as proxied by a financial gamble. We also explore selfreported general risk taking, and self-reported behavior in risk-related activities. Our participants are serious tournament bridge players, which gives them substantial experience in risk taking. We find some evidence that men with a 7-repeat allele $(7 \mathrm{R}+)$ of $D R D 4$ take more overall risk in bridge than individuals without this allele (7R-), and strong evidence that $7 \mathrm{R}+$ men take more economic risk in an investment game. Interestingly, these relationships are not found in the women in our study. Although the number of $7 \mathrm{R}+$ women in our sample is low, our results may reflect a gender difference in how the $7 \mathrm{R}+$ genotype affects behavior. Bridge masterpoints measure past success, thus reflecting playing skill and experience. We show that masterpoint level modulates the effect of the DRD4 gene in men in a highly important manner. We find that higher ranked $7 \mathrm{R}+$ men take significantly more good risks and significantly fewer bad risks than other men, whereas the opposite is found for less-expert $7 \mathrm{R}+$ men. This is the first study to distinguish between advantageous and disadvantageous risk taking. We identify a strong interaction among desirable risk taking behavior, measured success, and genetic variation. Considering other risk measures, we find no difference between 7R+ and 7R- individuals in general risk taking or in any of a number of other riskrelated activities. Our results indicate that the dopamine system plays an important role in explaining individual differences in risk taking in bridge and economic risk taking among men. Little relationship is found in other activities involving risk or among women.
\end{abstract}


Keywords Risk preferences; Dopamine; Risk taking; Contract bridge; Risk perception; Advantageous risks; DRD4.

JEL Classification C91, C93, D03, D81, D87, G0. 


\section{Introduction}

Many important decisions in life require choices among options that vary in their level of risk, as formalized say by the variance in the values of the possible outcomes an option implies. People tend to be risk averse in the domain of potential gains, i.e., they prefer a certain payoff over the same or possibly larger value in expectation for a variable payoff. By contrast, they tend to be risk loving in the domain of potential losses (Kahneman and Tversky 1979).

Risk preferences vary substantially across individuals, with women and older individuals typically being more risk averse than men and younger individuals (Barsky et al. 1997; Byrnes et al. 1999; Croson and Gneezy 2009; Dohmen et al. forthcoming). Some of this observed variation has been associated with biological factors (Apicella et al. 2008; Barnea et al. 2009; Carpenter et al. 2009; Cesarini et al. 2009a; Cesarini et al. 2009b; Coates et al. 2009; Crisan et al. 2009; Dreber et al. 2009; Kuhnen and Chiao 2009; Roe et al. 2009; Roiser et al. 2009; Sapienza et al. 2009; Zhong et al. 2009a; Zhong et al. 2009b; Zhong et al. 2009c; Calvet and Sodini 2010; though see Zethraeus et al. 2009). For example, twin studies on Swedish and Chinese twins suggest that genetic differences account for 20\% (Cesarini et al. 2009a) and 57\% (Zhong et al. 2009a), respectively, of individual differences in risk preferences in these two nations. (This discrepancy by nation could be explained by population differences such as local cultural norms, heterogeneity in environments, population differences in relevant gene frequencies, or in the risk measures used.)

Relatively little is known about the specific genetic determinants of individual variation in risk preferences, although a number of recent studies explore possible associations between specific genetic loci involved in chemical signaling in the brain (neurotransmission) and economic risk preferences (Carpenter et al. 2009; Crisan et al. 2009; Dreber et al. 2009; Kuhnen and Chiao 2009; Roe et al. 2009; Roiser et al. 2009; Zhong et al. 2009b; Zhong et al. 2009c). One neurotransmitter that has received particular attention is dopamine, due to its relation with reward processing in the brain. Activation of the dopaminergic reward pathways, and thus the release of dopamine neurotransmitters, can generate feelings of pleasure and well-being that become associated with the behaviors that triggered the activation. This makes dopamine a major player in reinforcement of behaviors that are associated with the anticipation of rewards.

Of the genetic markers for dopaminergic function, the dopamine receptor D4 gene (DRD4) has been identified as a candidate for explaining variation in economic behavior (Benjamin et al. 2008) and has received most of the attention in the literature thus far. ${ }^{1}$ As with many other genes, $D R D 4$ comes in various versions (“alleles”), which differ across individuals. There is a specific region of the gene which contains a repeated sequence of DNA base pairs. In different individuals, this sequence is repeated a different number of times (typically 2-11 times) on each of the two relevant chromosomes. The multiple versions of the gene are frequently divided into two dichotomous classes, those with fewer than 7 repeats on both chromosomes (7R-) and those with 7 or more repeats on at least one chromosome $(7 \mathrm{R}+)$

\footnotetext{
${ }^{1}$ See Appendix 1 for more information on DRD4 as well as the genotyping.
} 
(Ding et al. 2002). Functionally, individuals with the $7 \mathrm{R}+$ genotype are putatively less sensitive to dopamine uptake. Therefore $7 \mathrm{R}+$ individuals require higher levels of dopamine to produce a response of similar magnitude to that of 7R- individuals. In order for 7R+ individuals to achieve a comparably satiating response in the brain's corticomesolimbic dopamine reward pathway, they may engage in more stimulating behaviors than do 7Rindividuals. Such genetic variation in response to dopamine may thus contribute to individual differences in those personality and behavioral traits that are associated with the dopamine system. Such traits include novelty seeking (Ebstein et al. 1996; though see Munafo et al. 2008), pathological gambling (Perez de Castro et al. 1997), attention deficit/hyperactivity disorder (Li et al. 2006), behavioral disinhibition (Congdon et al. 2008), alcoholism (Laucht et al. 2007), impulsivity (Eisenberg et al. 2007; though see Munafo et al. 2008), sexual promiscuity (Garcia et al. in review), and many other behaviors. Risk taking in economic domains might also be influenced by the dopamine system. The goal of this study is to explore this relationship.

Our first aim with this study is to investigate the effect of variation in $D R D 4$ on risk taking related to economic decision making in a field setting where effective risk taking is a critical component of success, namely the game of contract bridge. As Warren Buffett observed: "Bridge is about weighing gain/loss ratios. You're doing calculations all the time" (Forbes 1997).

Meanwhile, riskier (i.e., higher variance) options often offer a higher expected return than safe alternatives. Such positive expected value risks can be considered "good" risks if their stakes are small relative to one's total endowment. Thus, someone with a million dollar portfolio would be taking a good risk on a coin flip that paid \$50 if heads but lost \$30 if tails. However there are also unequivocally "bad” risks, which offer higher variance together with a negative expected return. Gambling on roulette at a casino is such a risk, since the house takes a cut. $^{2}$

Exploring differences between good and bad risk taking is an issue that merits study, since both arise so often in real life. Successful retailers, for example, are always gambling on small risks. For example, an item offering a generous markup if sold on a timely basis may have to be sold at a loss. Judging which risks to take is a key to success in many arenas. The card game contract bridge provides an ecologically valid decision setting where it is possible to clearly discriminate between good and bad risks. A typical national pairs championship lasts four or six sessions, each with 26 hands. On any hand, there will be multiple decisions that involve both good and bad risks. It is interesting to note that bridge has been considered as a good model for financial decision making and has been used as part of hiring criteria for investment bankers (Cohan 2009).

Bridge is an ideal game to measure risk preferences for a few reasons: (1) the outcomes of risk taking in bridge have quantifiable consequences; (2) risk can be identified as either good or bad in character, and (3) potential subjects have had substantial experience outside of the

\footnotetext{
${ }^{2}$ Obviously, further elaboration is required if these small risks are correlated with one another.
} 
experimental setting with the types of questions required to elicit risk preferences. Bridge also offers a chance to explore how a measure of skill and experience in the decision setting affects outcomes. Masterpoints are awarded for success in certified bridge tournaments, with higher placements and larger and more important tournaments offering higher awards. Masterpoints, which are cumulative, thus reflect the combination of skill and experience. In short, bridge presents an attractive tool for studying risk preferences, since it enables us to look at risk taking among experienced risk takers in a non-laboratory yet controlled setting, with an objective measure of past decision making success.

The second goal of the paper is to investigate the relationship between $D R D 4$ and economic risk taking. Four recent studies have explored this possibility. Two of them find a positive association (Dreber et al. 2009, Kuhnen \& Chiao 2009). In a study of 94 young men, Dreber et al. (2009) find that 7R+ men put significantly more money into a risky investment than do 7R- men. They also examine a second dopamine receptor gene, DRD2, and find no relationship between genetic variation in DRD2 and risk taking. Kuhnen and Chiao (2009) similarly find a positive relationship between the $7 \mathrm{R}+$ genotype and risk preferences in a laboratory measure, using a sample of 65 men and women. They also find that the serotonin transporter gene 5-HTTLPR helps to predict risk preferences, as do Crisan et al. (2009), but not Roiser et al. (2009), whereas Zhong et al. (2009c) find a marginally significant relationship. Similarly, the findings on DRD4 by Dreber et al. (2009) and Kuhnen and Chiao (2009) have been contradicted. Carpenter et al. (2009), in a laboratory study of 140 men and women, find a marginally significant negative relationship between $7 \mathrm{R}+$ and risk taking. However, when the probabilities are ambiguous or when losses are possible, they find that $7 \mathrm{R}+$ individuals do make riskier choices than 7R- individuals, in accord with the other studies. In another study where participants are either given the dopaminergic precursor drug L-dihydroxyphenyalanine (L-DOPA) or a placebo, Eisenegger et al. (2010) do not find any main effect of $7 \mathrm{R}+$ on risk taking in a gambling task in the placebo group. However, $7 \mathrm{R}+$ men who have been given L-DOPA become more risk taking than 7R- men given the drug (Eisenegger et al. 2010). Given these somewhat mixed results, more research is needed to better understand the association between the $7 \mathrm{R}+$ genotype and economic risk taking, as well as other types of risk taking. We analyze only the single gene DRD4 in order to avoid issues related to multiple testing.

A major innovation of our study is that we identify and focus on a group of participants who had considerable experience with and were regularly engaged in risk taking situations. That is, we recruited participants who were serious tournament bridge players, as effective risk taking is a significant component of contract bridge expertise. To do so, we engaged 237 subjects at the Fall 2008 North American Bridge Championship in Boston, MA.

We first investigate the association between the $7 \mathrm{R}+$ genotype and risk taking in bridge. We hypothesize that $7 \mathrm{R}+$ individuals will be more risk taking than $7 \mathrm{R}$ - individuals. We then examine how variation in the $D R D 4$ gene interacts with an individual's level of past success in bridge to determine what types of risks in bridge are taken. 
Next we determine whether the positive association between the 7R+ genotype and economic risk taking found by Dreber et al. (2009) and Kuhnen and Chiao (2009) is identified in our study. While those prior studies mainly used college students, our participant pool is much more diverse in terms of age and background, though perhaps less diverse in terms of economic well being. ${ }^{3}$ A replication of the relationship between $7 \mathrm{R}+$ and economic risk taking in our sample would thus provide evidence for some generalizability of studies on students, as well as provide further support of a positive effect of $7 \mathrm{R}+$ on economic risk taking. Finally, in a largely exploratory analysis we also examine the connection between the $7 \mathrm{R}+$ genotype and self-reported general risk taking, as well as behavior in self-reported riskrelated activities. We hypothesize that $7 \mathrm{R}+$ individuals will be more risk taking than $7 \mathrm{R}$ individuals on all risk measures.

\section{Experimental design and procedure}

\section{a. The location and setup}

In this field study, as mentioned, 237 participants were recruited at the Fall 2008 North American Bridge Championship in Boston, Massachusetts. This major event lasted 10 days, with two 26-hand sessions per day, and more than 42,000 player sessions in total. Almost all of the participants were serious tournament bridge players who play many dozens of sessions per year. ${ }^{4}$ Tables for data collection were placed outside the major national championship game rooms one day and outside a secondary championship game room the following day. After reviewing and signing an informed consent form, participants provided a DNA sample by swishing $10 \mathrm{ml}$ of Scope ${ }^{\circledR}$ mouthwash from cheek to cheek for 45 seconds and spitting it back into a sterile $15 \mathrm{ml}$ collection tube (buccal wash). They then completed a bridge quiz and a questionnaire. The study was approved by Harvard University's institutional review board, and all genotyping procedures were additionally approved by Binghamton University's Human Subjects Research Review Committee. (See Appendix 2 Table A1 for more information on the participants.)

\section{b. The tasks}

Each participant first solved an incentivized bridge quiz that tested both their skill and risk taking propensity in bridge contexts. (See Appendix 3.) After this, participants took part in a risky gamble involving real financial payoffs. They then filled out a short questionnaire including a question on general risk taking and questions on behavior in risk-related activities. (See Appendix 4.) We also secured the masterpoint holding for each of our subjects.

\footnotetext{
${ }^{3}$ Our participant pool was overwhelmingly at least middle class, given the costs of traveling out of town to attend tournaments.

${ }^{4} 300+$ masterpoints, with an additional requirement that some fraction of them be won in regional or national championships, qualifies one to be a Life Master in competitive bridge. $79 \%$ of our participants have $300+$ masterpoints.
} 


\section{i. Bridge risk taking}

Each subject was given 10 minutes to make potentially risky decisions on 8 bridge hands. The hands were presented in the form of an incentivized bridge quiz. Such quizzes are a common format for teaching bridge and for assessing bridge skill, and are designed to reproduce frequently encountered bridge situations. They are regularly featured in bridge journals and are a staple of bridge books, and were thus familiar to the participants. The bridge quiz was prepared by world-renowned bridge expert Michael Rosenberg, and was announced as such. Each question presented the subject with a hand of cards, and in some cases the bids of some other players. Subjects were asked to choose which of several bids they preferred, and in some cases were also asked which bid they liked least. Each answer was assigned a performance score between 0 and 100. The subjects were informed that the highest total scorer over the eight hands in each of four masterpoint categories would receive a $\$ 250$ cash prize.

Our prime concern was individuals' risk propensities. Thus, each possible bid was assessed for its riskiness, the expected variability in the score it would receive in tournament play, in addition to its performance. Both performance and riskiness assessments were provided by Michael Rosenberg, the composer of the quiz. In addition, a second famed bridge expert, Michael Becker, also assigned a performance score and riskiness assessment to each bid. Becker manages the equivalent quiz section for The Bridge World, the leading bridge journal. The average performance score of the two experts was used to determine which bids were good and bad, and to award prizes. The two experts' riskiness assessments were averaged to provide the risk measure that indicated risk taking behavior.

The risk values were all normalized such that the minimum total value received is 0 and the maximum is $1 .^{5}$ Each subject's overall level of bridge risk taking was calculated by summing the risk values of each answer for the 8 questions. The bridge quiz was designed in such a way that for some questions, riskier answers earned higher scores (good risk questions), while in other questions riskier answers earned lower scores (bad risk questions). Each subject's level of good risk taking was calculated by summing the risk value of each answer for good risk questions, weighted by the performance score received for each question minus the average score on that question. Bad risk taking was computed equivalently, by summing over the bad risk questions, weighted by -1 times the performance score received for each question minus the average score.

\section{ii. Economic risk taking}

Participants chose how to allocate money in an incentivized financial investment task, a modified version of a measure used in Gneezy and Potters (1997). The same task was used in Dreber et al. (2009), where a positive relationship was found between the amount invested and the presence of the $7 \mathrm{R}+$ genotype in a sample of male college students. Apicella et al. (2008) also found a positive relationship between risk taking in the same task and both

\footnotetext{
${ }^{5}$ One possible response to one of the questions in the 8 question quiz was regarded by the experts as so excessively risk averse that it received a risk score of -1 . 3 out of 237 participants gave this response. No other score was below 0 .
} 
circulating testosterone and a proxy of pubertal testosterone exposure in the same male sample as Dreber et al. (2009).

In the investment task, participants started with \$250, of which they could choose an amount \$X to devote to a risky investment. The outcome of the risky investment was decided by a coin flip. If successful, the amount $\mathrm{X}$ was multiplied by 2.5; if unsuccessful, the amount $\mathrm{X}$ was lost. The remainder ( $\$ 250$ - \$X), the "safe investment" was kept regardless of the outcome of the coin flip. Thus if the coin flip was successful, participants ended up with $\$ 250+\$ 1.5 X$; otherwise \$250-\$X. Participants were informed that after everyone had made an investment decision, three individuals would be randomly selected to play for real money, bound by the investment amount they had indicated. Investing in this gamble increases both the expected value and variance (risk) of the outcome. Hence, participants had to weigh the two factors in determining their value for $\mathrm{X}$. An individual's choice of $\mathrm{X}$ provides our measure of economic risk-taking.

\section{iii. General risk taking and questionnaire}

The questionnaire included a self-reported risk question used by Dohmen et al. (forthcoming) that asked about the individual's willingness to take risks on an 11-point Likert scale: "Are you a person who is generally prepared to take risks or do you try to avoid taking risks?” In the sample of approximately 22,000 individuals in Dohmen et al., willingness to take risks correlated negatively with age and female gender, but related positively to height and parental education. In a representative sample of 450 individuals, they found that this measure provides a good proxy of actual risk taking behaviors, such as traffic offenses, portfolio choice, smoking, occupational choice, participation in sports and migration. Dohmen et al. interpret this question to concern risk perception. We impose less interpretation and refer to it as general risk taking propensity.

Our questionnaire also included questions on gender, age (binned with options $<20,20-30$, 30-40, 40-50, 50-60, 60-70, 70-80, 80-90 and 90+), height (analyzed in cm), sexual orientation, marital status, ethnicity, smoking and alcohol habits, proportion of assets invested in stocks and bonds, and whether participants had ever started a company. Most of the variables are categorical. (See Appendix 3 for the actual questionnaire.) Logic would suggest that a number of these questions are related to risk preferences.

For example, the proportion of assets invested in stocks and in bonds relates to financial risk taking. In our analysis we disregard participants who answered “don’t know” (corresponding to 10 participants for stocks and 2 participants for bonds). Participants were given intervals that they could choose among, in increments of $10 \%$ (see Appendix 3). If the participant chose the "less than $10 \%$ " category, it is coded as 0.05 , " $10-20 \%$ " is coded as 0.15 , etc. The percentages invested do not add up to one, since there are other unspecified categories of investment. We assume that on average these unspecified investments are instruments that are less risky than stocks (such as money market funds or savings accounts), making proportion of assets in stocks a positive indicator of risk taking. The effect on bonds is more ambiguous, since bonds are more risky than a savings account but less risky than stocks. For this reason we create a variable that is stocks/(stocks+bonds). 
Similarly, we take whether the participant had ever started a company as a proxy of entrepreneurship, a positive risk indicator. Moreover, participants indicated how many cigarettes they smoke each month and how many alcoholic drinks they consume each month, both risk related activities. More specifically, there is a large literature linking variation in $D R D 4$ to addiction. To analyze this we create two dummy variables: each takes the value 0 if the answer is 0 to the specific question (i.e., never drink or smoke), and 1 otherwise.

\section{Data analysis and results}

When the dependent variable is continuous, we use linear regressions (OLS) with robust standard errors; when it is binary, we employ a logit regression with robust standard errors. We conservatively report two-tailed test statistics, although clear ex ante predictions exist for most tests: that $7 \mathrm{R}+$ will be positively associated with risk. Basic demographics are presented in Appendix 2 Table A1.

Variation in the $D R D 4$ gene was successfully analyzed for 190 men and women of our 237 participants. An additional 13 individuals were analyzed who did not report their gender. Genotype frequencies in our sample are as follows. Among the 105 men for whom DRD4 data was obtained, 19 were $7 \mathrm{R}+(18.1 \%)$. Among the 85 women successfully genotyped, only 6 were $7 \mathrm{R}+(7.1 \%)$. These two frequencies are significantly different (chi ${ }^{2}$ test: $\mathrm{p}=0.025$ ). This irregularity is surprising, as there is no previous evidence for the population frequency of $7 \mathrm{R}+$ varying with gender. It may suggest a bias in the propensities of the women, compared to men, who are drawn to competitive bridge, which could also lead to systematic differences in the effect of the $7 \mathrm{R}+$ genotype between men and women in our study. Thus, we examine a $7 \mathrm{R}+$-by-gender interaction term in our analyses. When the interaction is significant, we also analyze men and women separately. Out of the 13 individuals with unknown gender, 2 are $7 \mathrm{R}+$. We find no significant differences in $7 \mathrm{R}+/-$ frequency based on age or sexual orientation. We use a binary variable that takes the value 1 if an individual is $7 \mathrm{R}+$ and 0 otherwise.

\section{a. Correlation among risk measures}

Dohmen et al. (forthcoming) and Roe et al. (2009) find only limited associations among risk measures from different domains. Here we correlate the different risk measures with each other, expecting positive associations in a simple correlation analysis. Correlating economic risk taking and general risk taking in the male and female subsamples separately (including non-genotyped participants), we find these measures to be positively correlated for both men and women (men: $\mathrm{r}=0.19, \mathrm{p}=0.048$, women: $\mathrm{r}=0.26, \mathrm{p}=0.015$ ). (See Tables A2 and A3.) Given these relationships, and related past evidence, we expect the $7 \mathrm{R}+$ genotype to have a similar effect on economic risk taking and general risk taking. Economic risk taking is not correlated with risk taking in bridge. The significance values are: overall bridge risks (men: $\mathrm{p}=0.952$, women: $\mathrm{p}=0.706$ ), good bridge risks (men: $\mathrm{p}=0.360$, women: $\mathrm{p}=0.540$ ), and bad bridge risks (men: $\mathrm{p}=0.975$, women: $\mathrm{p}=0.0 .945$ ). Similarly, general risk taking does not relate to bridge risk taking. The significance values are: overall bridge risks (men: $p=0.843$, women: $\mathrm{p}=0.261$ ), good bridge risks (men: $\mathrm{p}=0.751$, women: $\mathrm{p}=0.693$ ), and bad bridge risks 
(men: $\mathrm{p}=0.955$, women: $\mathrm{p}=0.0113$ ). Overall risk taking in bridge is positively correlated with bad bridge risks in men $(\mathrm{r}=0.61, \mathrm{p}<0.0001)$ as well as in women $(\mathrm{r}=0.53, \mathrm{p}<0.0001)$. Overall risk taking in bridge is not related to good risk taking in men $(\mathrm{r}=0.13, \mathrm{p}=0.16)$, but is in women ( $\mathrm{r}=0.36, \mathrm{p}=0.0003$ ), Good and bad bridge risk taking are negatively correlated for both men ( $\mathrm{r}=-0.034, \mathrm{p}=0.0001)$ and women $(\mathrm{r}=-0.25, \mathrm{p}=0.013)$. This last fact leads to our most intriguing bridge result; that a cluster of factors positively predicts good risk taking but negatively predicts bad risk taking.

\section{b. Bridge risk taking}

\section{i. Overall risk taking in bridge}

We regress overall risk taking in bridge on the $7 \mathrm{R}+$ binary variable. (See Table A4.) There is no significant relationship between $7 \mathrm{R}+$ and overall risk taking in bridge $(\mathrm{p}=0.939)$. When controlling for variables known to be important for risk such as gender, age and height, as well as masterpoints, a significant relationship $(\mathrm{p}=0.491)$ still does not emerge. However, there is a marginally significantly different effect of $7 \mathrm{R}+$ on risk taking in men versus women, seen by interacting the variable for being a woman and $7 \mathrm{R}+($ coeff $=-1.09, \mathrm{p}=0.065) .7 \mathrm{R}+$ may thus have different effects on overall risk taking in bridge in men and women in our sample, and we thus pursue the analysis of men and women separately.

Performing a separate analysis of the men in our sample, we find that $7 \mathrm{R}+$ men take marginally significantly more overall risk in bridge than $7 R$ - men (coeff $=0.519, p=0.098$ ), controlling for age, height and masterpoints. $7 \mathrm{R}+$ men take $17.3 \%$ more risk than $7 \mathrm{R}$ - men in bridge when we include other control variables, which corresponds to 0.40 standard deviations (Figure 1). Not including control variables, however, the relationship between 7R+ and overall risk taking is not significant $(\mathrm{p}=0.407)$. For women only, $7 \mathrm{R}+$ is trending in the negative direction but is non-significant when controlling for age and height $(p=0.26)$ as well as when not including control variables $(\mathrm{p}=0.155)$. Height is negatively related to overall risk taking in bridge for women (coeff $=-0.047, \mathrm{p}=0.008$ ). 


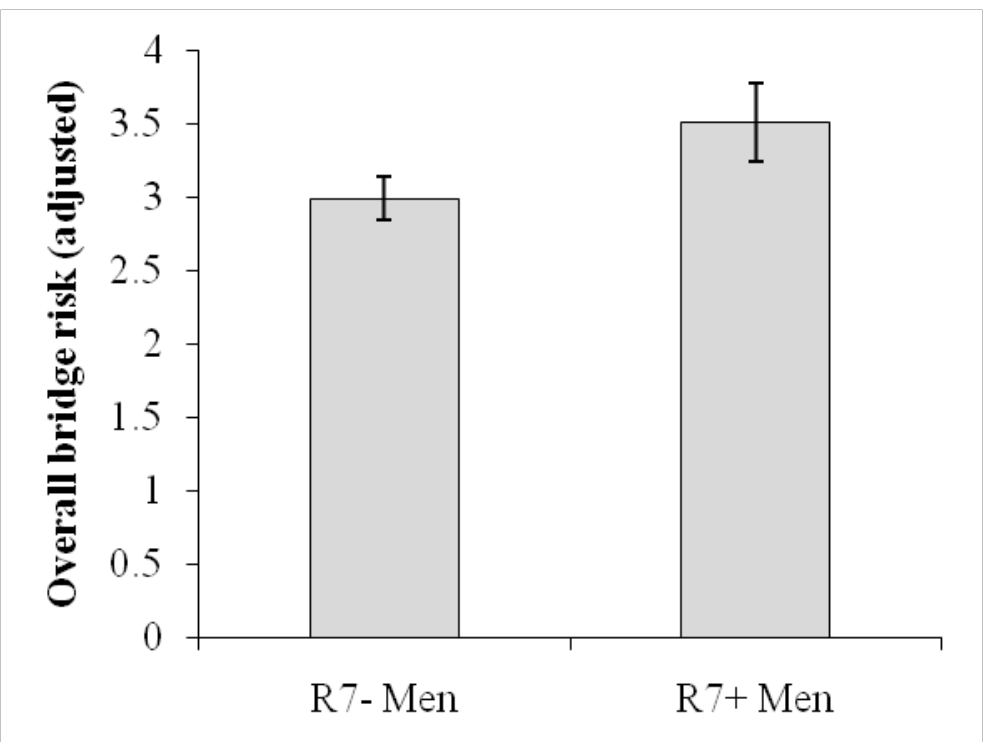

Figure 1. Overall risk taking in bridge among men. Visualized bridge risk scores are adjusted to take into account the effect of masterpoints, age and height utilizing a multi-variate regression (Table A4 (5)): shown is bridge risk - 0.041*age + 0.002*height $0.236 * \log 10$ (masterpoints +1$)$. Error bars indicate standard error of the mean.

\section{ii. Good and bad risk taking in bridge}

Looking at good and bad risk taking separately, we find no significant effect of 7R+ (good risk: $\mathrm{p}=0.594$, bad risk: $\mathrm{p}=0.727$ ). (See Table A5.) Controlling for gender, age, height and masterpoints, the effect remains insignificant (good risk: $p=0.434$, bad risk: $p=0.869$ ), and the interaction effects between being a woman and $7 \mathrm{R}+$ are insignificant. We thus do not analyze the male and female samples separately at this point.

\section{iii. Interactions between $7 \mathrm{R}+$ and past success}

The regressions on risk taking in bridge, however, hide an interesting gene-experience interaction in explaining good and bad risk taking in bridge. ${ }^{6}$ (See Table A6.) Masterpoints are a direct measure of past success in competitive bridge. We thus ask whether the genetic predisposition represented by $7 \mathrm{R}+/$ - interacts with the success - due to combination of skill and experience - reflected by masterpoints to predict good and bad risk taking. We include controls for gender, age and height throughout. We also test for interactions between the variables and being a woman.

We find no significant effects for either good or bad risk taking when only interacting 7R+ and masterpoints. However, after controlling for gender, a striking relationship emerges. The effect of $7 \mathrm{R}+$ and masterpoints is dramatically different in men and women (three-way interaction between $7 \mathrm{R}+$, masterpoints and gender: good risk taking, $\mathrm{p}=0.001$; bad risk taking, $\mathrm{p}=0.012$ ). We therefore analyze the male and female samples separately.

\footnotetext{
${ }^{6}$ Performing a similar analysis of overall risk taking in bridge show no significant interactions between $7 \mathrm{R}+$ and masterpoints.
} 
Starting with good risk taking in bridge in the male sample, we find a significant negative main effect of $7 \mathrm{R}+$ (coeff=-32.18, $\mathrm{p}=0.001$ ). However, we identify a significant positive interaction effect of $7 \mathrm{R}+$ and masterpoints (coeff=10.46, $\mathrm{p}<0.001$ ). Below we use the term accomplished to indicate more past bridge success as measured by masterpoints. These two results indicate that more accomplished men with $7 \mathrm{R}+$ take more good risk than other men, while less accomplished 7R+ men take less good risk than other men. The net coefficient which is the sum of the coefficient on masterpoints and the interaction variable is highly significant $(\mathrm{p}<0.0001)$ and positive. ${ }^{7}$ This suggests that more accomplished $7 \mathrm{R}+$ men also take significantly more good risk in bridge than less accomplished 7R+ men.

Our most intriguing results are shown clearly in Figures 2. Figure 2A shows the strong relationship between $7 \mathrm{R}+$ and masterpoints for good risk taking in bridge. Figure 2C, by contrast, shows almost no relation between $7 \mathrm{R}$ - and masterpoints for good risk taking. Considering bad risk taking in the male sample, the main effect of $7 \mathrm{R}+$ is positive and significant (coeff $=102.81, \mathrm{p}=0.026$ ). However, there is a significant negative interaction between $7 \mathrm{R}+$ and masterpoints (coeff $=-30.93, \mathrm{p}=0.020$ ). The net coefficient of masterpoints and the interaction variable is significant and negative $(\mathrm{p}=0.036){ }^{8}$ As shown in Figure $2 \mathrm{~B}$, more accomplished $7 \mathrm{R}+$ men take less bad risk than less accomplished $7 \mathrm{R}+$ men. Figure $2 \mathrm{D}$ shows little relation between masterpoints and bad risk taking among 7R- men.

In a separate analysis solely of women, there is no significant effect of $7 \mathrm{R}+$ alone nor if interacted with masterpoints for either good or bad risk taking. ${ }^{9}$ However, the sample of $7 \mathrm{R}+$ women is very small; thus the analysis is not particularly informative.

\footnotetext{
${ }^{7}$ To get the net predicted effect for any player we must multiply the interaction coefficient by his $\log 10$ (masterpoints+1) and add to the main effect coefficient.

${ }^{8}$ See footnote 7 .

${ }^{9}$ For females, the one finding is that height is significantly negatively (coeff $=-0.95, p=0.035$ ) related to bad risk taking.
} 


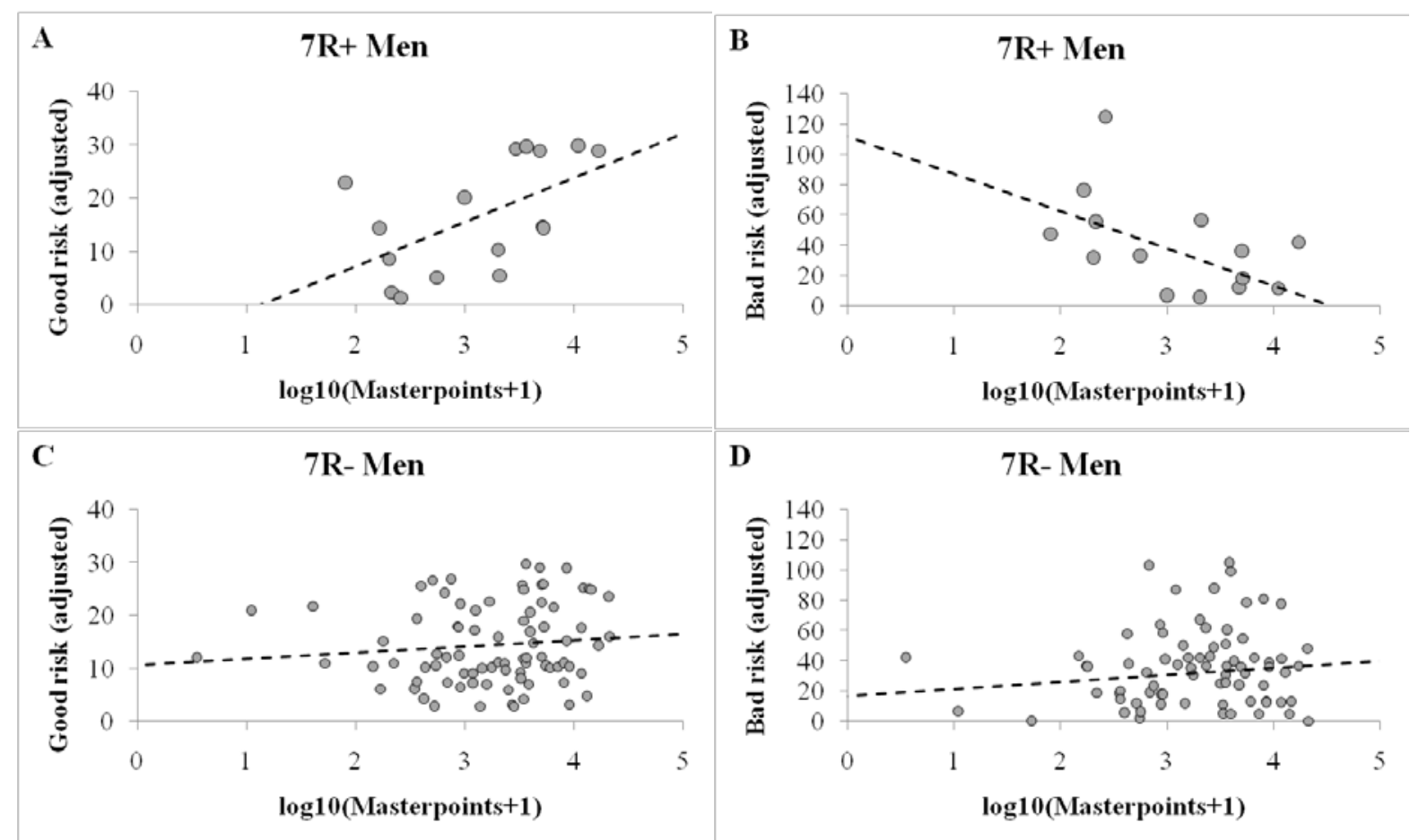

Figure 2. Good risk-taking $(A, C)$ and bad risk-taking $(B, D)$ as a function of masterpoints, by DRD4 genotype. Visualized good and bad bridge risk scores are adjusted to take into account the effects of age and height utilizing a multi-variate regression (Table A6 (3) \& (7)): shown is good risk $+0.873 *$ age $-0.013 *$ height, and bad risk $-0.640 *$ age $+0.017 *$ height.

\section{c. Economic risk taking}

Our dependent variable for economic risk taking is the amount of money participants put at risk in our 2.5 to 1 gamble on a coin flip. We regress economic risk taking on the $7 \mathrm{R}+$ binary variable. (See Table A7.) 7R+ individuals (both genders combined) are not significantly more risk taking than $7 \mathrm{R}$ - individuals $(\mathrm{p}=0.266)$, even when we control for variables previously found to affect economic risk taking $(\mathrm{p}=0.183)$, though the effect is in the hypothesized direction. Being a woman and the variable age are both significantly related to economic risk taking (female: coeff=-70.20, $\mathrm{p}<0.001$, age: coeff=-9.87, $\mathrm{p}=0.028$ ). However, there is a significantly different effect of $7 \mathrm{R}+$ on men and women, seen by interacting the variable for being a woman and $7 \mathrm{R}+$ (coeff=-70.24, $\mathrm{p}=0.049$ ). As we found for overall risk taking in bridge, this result indicates that $7 \mathrm{R}+$ may have different effects on economic risk taking in men and women in our sample, and we continue with the analysis of men and women separately.

Looking only at males, $7 \mathrm{R}+$ men take significantly more risk than their $7 \mathrm{R}$ - counterparts (coeff=39.19, $\mathrm{p}=0.004$ ) when controlling for age and height. The effect is sizeable: $7 \mathrm{R}+$ men take $22 \%$ more economic risk than $7 \mathrm{R}$ - men, corresponding to 1.13 standard deviations (Figure 4). Age is also significantly related (coeff $=-13.3, \mathrm{p}=0.013$ ); older individuals take less risk. Height is not related ( $\mathrm{p}=0.189)$. The effect of $7 \mathrm{R}+$ on risk taking is marginally significant when neither age nor height is controlled (coeff $=28.73$, $\mathrm{p}=0.082$ ). Looking at women only, the effect of $7 \mathrm{R}+$ is non-significant when controlling for age and height $(\mathrm{p}=0.421)$ and when 
neither covariate is included $(\mathrm{p}=0.449) .{ }^{10}$ It is interesting to note, however, that the sign of the effect of the $7 \mathrm{R}+$ genotype on economic risk taking is negative in the female sample, the opposite of what is observed in the male sample.

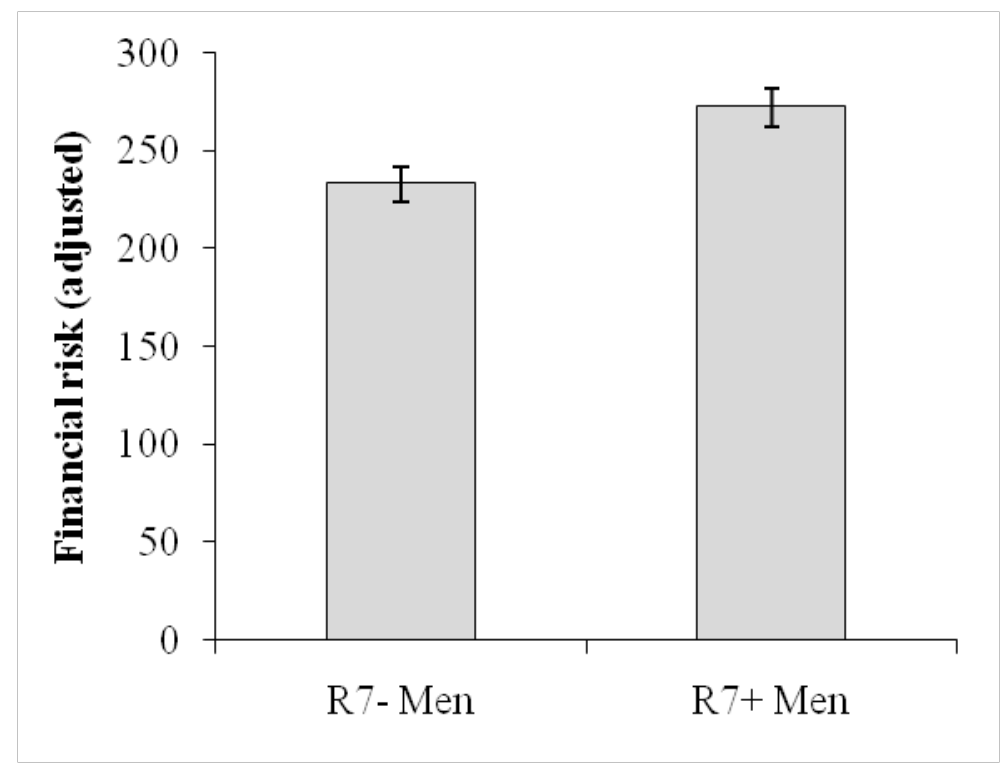

Figure 3. Financial risk taking in risky investment measure. Visualized financial risk scores are adjusted to take into account the effect of age and height utilizing a multi-variate regression (Table A7 (5)): shown is investment $+13.30 *$ age $-0.153^{*}$ height. Error bars indicate standard error of the mean.

\section{d. General risk taking/risk perception and risk-related activities}

\section{i. General risk taking}

Given the acute effect of $7 \mathrm{R}+$ on economic risk taking in males, we might expect $7 \mathrm{R}+$ to also affect self-reported general risk taking. Indeed, in our sample economic risk taking was significantly positively correlated with general risk taking. Nevertheless, looking at the whole sample, perhaps surprisingly, 7R+ has no significant effect when controlling for gender, age and height $(\mathrm{p}=0.519)$, nor when no controls are included $(\mathrm{p}=0.982)$. (See Table A8.) We also find no significant effect of $7 \mathrm{R}+$ on general risk taking for either gender separately, or that the effect differs between the genders. The only significant predictor of general risk taking is gender, where women report taking fewer risks (coeff=-1.24, $\mathrm{p}=0.002$ ). It is interesting to note that Dohmen et al. (forthcoming) had about $7 \%$ of their sample answer 0 (lowest risk taking) on this risk question, whereas in our sample no one answered 0 . This could be due to a variety of factors. There could be more risk takers in our sample, or more familiarity in thinking about risk questions. It could also be a framing response: the individuals were in the midst of a bridge tournament, where risk taking is a prime ingredient. It is also interesting to note that Cesarini et al. (2009b), using the same general risk taking question in a twin study, find a genetic component (of about 35\%).

\footnotetext{
${ }^{10}$ The lack of statistical significance of among women is not surprising given the very low number of $7 \mathrm{R}+$ women.
} 


\section{ii. Correlations among risk measures and activities}

To begin, we ask if our risk measures (overall bridge risk taking, good bridge risk taking, bad bridge risk taking, economic risk taking and general risk taking) are associated with riskrelated activities. Note that this section is largely exploratory. (See Tables A2 and A3 for correlation matrices.) We look at men and women separately, since there is a strong gender difference in many of the measures.

First we consider overall, good and bad risk taking in bridge. Among women but not men, both overall and good risk taking in bridge are positively correlated with entrepreneurship (having started at least one company) (overall bridge risk: $r=0.21, p=0.037$, good risk: $r=0.20$, $\mathrm{p}=0.047$ ). There are no other significant correlations between risk taking in bridge and riskrelated activities.

Second, we consider economic risk taking. Correlating economic risk taking with stocks/(stocks+bonds), and including both genotyped and non-genotyped participants, the relationship is not significant for either men or women. We also find no relationships between economic risk taking and entrepreneurship. Note however, that about half of both men and women in our sample have started a company. This is many times higher than the national (US) average and validates an assumption motivating this study, namely that serious bridge players are a group accustomed to taking consequential risks. There are no significant associations between economic risk taking and being a smoker. Looking at the relationship between economic risk taking and drinking alcohol ( $0=$ never drink, $1=$ =sometimes drink), the relationship is not significant for either men or women.

We now consider general risk taking. There is no significant relationship between general risk taking and our variable stocks/(stocks+bonds) in the male or female subsamples. General risk taking proved to be not related to having started a company, smoking or drinking alcohol for women. For men, however, the relationship between general risk taking and entrepreneurship is significant and in fact negative $(\mathrm{r}=-0.25, \mathrm{p}=0.007)$. There is also a marginally significant positive relationship between general risk taking and drinking alcohol in the male subsample $(\mathrm{r}=0.18, \mathrm{p}=0.06)$.

\section{iii. $7 \mathrm{R}+$ and risky activities}

To explore the potential effects of the 7R+ genotype on investment allocations, we look at our variable stocks/(stocks+bonds). In a regression analysis, we find no significant relationship between the $7 \mathrm{R}+$ genotype and investment in stocks and bonds either with covariates $(p=0.296)$ or without them ( $p=0.394)$. (See Table A9.) Being female is however negatively associated with more risky investments (coeff $=-0.071, \mathrm{p}=0.01$ ), whereas height is positively correlated (coeff $=0.0007, \mathrm{p}<0.001$ ). Both effects are in the expected direction. The interaction effect between $7 \mathrm{R}+$ and being a woman is not significant, thus we do not look at the male and female samples separately.

Exploring our entrepreneurship variable (whether participants have started a company or not) in a logit regression, this variable is not significantly correlated with $7 \mathrm{R}+$ in the total sample 
when controls are included ( $\mathrm{p}=0.725$ ) or not ( $\mathrm{p}=0.948)$, nor is the interaction effect between $7 \mathrm{R}+$ and being a woman. The control variables female, age and height are also not related. (See Table A9.)

For smoking and drinking alcohol, we perform logit regressions and find no significant relationship between $7 \mathrm{R}+$ and smoking or drinking with control variables $(\mathrm{p}=0.342$ resp. 0.804 ) or without control variables ( $\mathrm{p}=0.198$ resp. $\mathrm{p}=0.966$ ). Among the control variables, the only marginally significant relationship with smoking is age (coeff $=0.34, p=0.067$ ), whereas for drinking there is a marginally significant relationship with height (coeff $=0.04, p=0.062$ ). (See Table A10.) There are no smoking 7R+ women; thus we do not include an interaction variable between $7 \mathrm{R}+$ and being a woman in the analysis of smokers. For alcohol, this interaction is not significant.

\section{Discussion and conclusion}

An emerging body of literature explores the potential role of genetic factors in explaining individual variation in economic decision making. Twin studies and molecular genetics studies have been used to address behaviors such as altruism in the dictator game (Knafo et al. 2007; Cesarini et al. 2009a; Israel et al. 2009), rejection behavior in the ultimatum game (Wallace et al. 2007), trust behavior in the trust game (Cesarini et al. 2008), risk preferences (Barnea et al. 2009; Carpenter et al. 2009; Cesarini et al. 2009a; Cesarini et al. 2009b; Crisan et al. 2009; Kuhnen and Chiao 2009; Roe et al. 2009; Zhong et al. 2009a; Zhong et al. 2009b; Zhong et al. 2009c; Calvet and Sodini 2010; Eisenegger et al. 2010), sensitivity to the framing effect (Crisan et al. 2009; Roiser et al. 2009) and behavioral aggression in an economic game (McDermott et al. 2009). This literature suggests that genetic contributions to individual (biological) differences have substantial implications for economic and behavioral studies. Further, genetic inheritance is a potentially important mechanism to consider when interpreting correlations in preferences between parents and offspring, and when considering determinants of preferences more generally. This is not to say that heritable genetic factors fully determine behavior; experience and environment clearly matter. But the addition of genetic factors to economic models is highly likely to improve our understanding of behavior, thereby improving our models and increasing their predictive power.

The focus of this study is on risk taking. The vast literature on this topic reports significant heterogeneity in levels of risk aversion within and across populations (Barsky et al. 1997; Donkers et al. 2001; Halek and Eisenhauer 2001; Dohmen et al. forthcoming). Risk preferences appear to be a complex and multi-dimensional trait, perhaps explaining why some studies report correlations across risk domains (Barsky et al. 1997; Guiso and Paiella 2005; Dohmen et al. forthcoming), whereas others do not (Anderson and Mellor 2009). Risk preferences have been analyzed using a wide variety of experimental approaches (Slovic 1964), and this presumably accounts for some of the reported variance (though there is a discussion of how to extract innate risk attitudes from experimental work, see e.g., Schoemaker 1993). However, holding the experimental methodology constant, significant differences in risk preferences emerge across varying populations (Hsee and Weber 1999). Though a variety of environmental forces, e.g., culture, no doubt contribute to such results, 
genetic variation may be an important contributor as well. ${ }^{11}$ Whereas genes do not vary across an individual's lifespan, the environment does. This may explain the within participant heterogeneity observed by e.g., Isaac \& James (2000).

The study we present here explores variation in the dopamine receptor gene $D R D 4$. This gene has previously been related to risk preferences in the economic domain, though with some inconsistent results. Two studies found a positive relationship between the $7 \mathrm{R}+$ genotype and economic risk taking; one study found a negative relationship with economic risk taking, and another study found no relationship. Our analysis seeks to deepen the field's understanding of $7 \mathrm{R}+$ 's relationship to risk taking by looking at different risk measures related to economic decision making and a variety of risk-related activities, with a focus on risk taking in the card game contract bridge as well as economic risk taking.

We find some evidence of variation in $D R D 4$ explaining the individual variation we observe in overall risk taking in bridge, but only in men. $7 \mathrm{R}+$ men take marginally significantly more overall risk in bridge than other men. More intriguing, our results emphasize the importance of interactions between genetic predispositions and life experiences. Particularly, we examine accomplishment due to skill and experience in a setting where the subjects have had a great deal of training in critical reasoning, as illustrated by decision making by the participants in a national bridge championship. We find a gene-accomplishment interaction in men, where more accomplished $7 \mathrm{R}+$ men take more good risk and less bad risk in bridge than other individuals, where good and bad risks are defined in terms of their expected value. Moreover, less accomplished 7R+ men take significantly less good risk and more bad risk than other men. This disparity could be due to a "bounded awareness" (Bazerman and Chugh 2005; Chugh and Bazerman 2007) whereby less skilled bridge players have access to the same information as more skilled players, but are focusing on a misleading subset. Or alternatively they may indeed be less capable of disentangling the probabilities and outcomes, closer to a state of ignorance (as per Hogarth and Kunreuther 1995). ${ }^{12}$ Either way, our results provide evidence of the importance of interactions between genetic predispositions and life experience in explaining variation in behavior among individuals.

In the domain of economic risk taking, we find that $7 \mathrm{R}+$ men take more economic risk than 7R-men, and that this relationship is highly significant. These results are in line with Dreber et al. (2009), who use the same economic risk measure in a sample containing men only. Among women, there is a non-significant but trending negative relationship. This finding, as well as the result on general risk taking in bridge, lends some support to the possibility that there may be systematic differences in the types of men and women in our sample, something that is further supported by the fact that the difference in frequency of the 7R+ genotype between men and women is significant. This difference across genders remains a puzzle to be disentangled in the future studies. While nothing (to our knowledge) has been reported on the

\footnotetext{
${ }^{11}$ Indeed, the prevalence of many alleles varies significantly across populations. In the case of the 7R+ genotype of $\mathrm{DRD}$, allele frequencies in populations ranging from $0 \%$ to $78 \%$ have been reported in a study of prevalence rates across the globe (Chen et al. 1999).

${ }^{12}$ Similarly, following Johnson et al. (1993), perhaps less skilled 7R+ men are more biased in their probability assessments than skilled 7R+ men are, and as one gains more experience, either skills are honed or the worst risk takers are weeded out.
} 
7R+ genotype acting differently in men and women in general, or in the other two studies on DRD4 and economic risk taking that include both genders, our sample was chosen to be far from representative. It seems quite plausible that systematic differences exist in the types of men versus women attracted to serious bridge tournaments, or that extensive experience with risk taking in bridge alters the behavior of female bridge players, and that these differences explain the gender differences in both the frequency of the $7 \mathrm{R}+$ genotype and its effects that we observe. Alternatively, it is entirely possible that the negative trend in women is a statistical anomaly arising from the extremely small of number of $7 \mathrm{R}+$ women. It is interesting to note that the frequency of the $7 \mathrm{R}+$ genotype in our study is low for both men and women compared to previous studies (e.g., Carpenter et al. 2009, Kuhnen and Chiao 2009). It is also conceivable that the observed effect of the $7 \mathrm{R}+$ genotype in men is a false positive, but this seems unlikely given the size of the sample and other replications of this finding (Dreber et al. 2009, Kuhnen and Chiao 2009). Additionally, the economic risk taking measure that we used in this study only entails good risk, since the expected value of taking risk always is significantly greater than the certain value. Thus, it is important to explore in a future study to what extent experience with economic risk taking interacts with $7 \mathrm{R}+$ when looking at both good and bad risk taking on a pure monetary basis.

Despite the significant positive correlation between economic risk taking and general risk taking, and the positive effect of $7 \mathrm{R}+$ among men on economic risk taking, we find no relationship between $7 \mathrm{R}+$ and self-reported general risk taking. It could perhaps be the case that $7 \mathrm{R}+$ individuals don't realize that many of their behaviors are considered risky by others. We also find no support for a relationship between $7 \mathrm{R}+$ and the self-reported risk-related activities explored in our study. The lack of correlation between $7 \mathrm{R}+$ and self-reported risk taking is in line with the results of Roe et al. (2009), who find different genes correlating with economic and psychological risk measures. This does not imply that risk preferences are unstable, nor that they are context dependent. In fact, Dohmen et al. (forthcoming) find evidence for a single trait operating in the different risk contexts they explore, but with some variation across contexts, perhaps due to differences in risk perception. In their study, it is interesting to note, the general risk question effectively predicted all behaviors (including portfolio choice and smoking). That was not the finding in our study, though our sample is substantially smaller and drawn from a specific population. Moreover, general risk taking/risk perception has been shown to have a genetic component (Cesarini et al. 2009a; Crisan et al. 2009); thus perhaps genes other than $D R D 4$ are involved in that process.

Risk preferences are of great practical importance given their relationship with economically significant behaviors such as competitiveness, career choice, savings behavior, and pension choice, among many others. We are only beginning to understand the potential role of variation in specific genes, such as the dopamine gene $D R D 4$, in contexts involving risk preferences. This implies that more studies on DRD4 are merited, as well as the identification of other genes which may influence risk preferences in the domain of economic games, psychological measures, and human behavior in the field. Understanding risk preferences is essential for understanding economic behavior, and incorporating the role of genetics into that understanding is a central interdisciplinary challenge in the study of human behavior. 


\section{Acknowledgements}

We thank the study participants at the Fall 2008 North American Bridge Championship in Boston, MA and Mark Aquino, president of the host Eastern Massaschusetts Bridge Association, for making this study possible. We thank Rita Spathis, Alexandra Taylor and Miguel G. Vilar for valuable laboratory assistance. We thank Johan Almenberg, Suzanne Cooper, Magnus Johannesson, Dan Levy, Laura Malick, and seminar participants at Harvard Kennedy School, Olin Business School, Simon Fraser University, Stockholm University, the 4th Nordic Conference on Behavioral and Experimental Economics and the Workshop on Biological Basis of Behavioral Economics for helpful comments, and the Berkman Center for Internet and Society for funding. DGR gratefully acknowledges support from the John Templeton Foundation's Foundational Questions in Evolutionary Biology Prize Fellowship.

\section{References}

Anderson, L., \& Mellor, J. (2009). Are risk preferences stable? Comparing an experimental measure with a validated survey-based measure. Journal of Risk and Uncertainty 39, 137-160

Apicella, C.L., Dreber, A., Campbell, B., Gray, P.B., Hoffman, M., \& Little, A.C. (2008). Testosterone and financial risk preferences. Evolution and Human Behavior 29, 384-390

Barnea, A., Cronqvist, H., \& Siegel, S. (2009). Nature or nurture: What determines investor behavior? SSRN Working Paper.

Barsky, R.B., Juster, F.T., Kimball, M.S., \& Shapiro, M.D. (1997). Preference parameters and behavioral heterogeneity: An experimental approach in the health and retirement study. Quarterly Journal of Economics 112, 537-579

Bazerman, M. and D. Chugh (2005). Bounded Awareness: Focusing Failures in Negotiation. In: L. Thompson (ed.) Frontiers of Social Psychology: Negotiation, Psychological Press.

Benjamin, D.J., Chabris, C.F., Glaeser, E., Gudnason, W., Harris, T.B., Laibson, D., Launer, L., \& Purcell, S. (2008). Genoeconomics. In: Weinstein M, JW Vaupel \& KW Wachter (ed.) Biosocial Surveys. Committee on Population, Division of Behavioral and Social Sciences and Education. The National Academies Press, Washington, D.C.

Byrnes, J.P., Miller, D.C., \& Schafer, W.D. (1999). Gender differences in risk taking : A metaanalysis. Psychological bulletin 125, 367-383

Calvet, L.E., Sodini, P., 2010. Twin Picks: Disentangling the Determinants of Risk-Taking in Household Portfolios. In: NBER Working Paper Series

Carpenter, J., Garcia, J.R., Lum, J.K., 2009. Can Dopamine Receptor Genes Explain Economic Preferences and Outcomes?

Cesarini, D., Dawes, C.T., Fowler, J.H., Johannesson, M., Lichtenstein, P., Wallace, B., 2008. Heritability of cooperative behavior in the trust game. Proc Natl Acad Sci U S A 105, 3721-6

Cesarini, D., Dawes, C.T., Johannesson, M., Lichtenstein, P., Wallace, B., 2009a. Genetic variation in preferences for giving and risk-taking. Quarterly Journal of Economics 124, 809-842

Cesarini, D., Johannesson, M., Lichtenstein, P., Sandewall, Ö., Wallace, B., 2009b. Financial risktaking behavior is genetically transmitted. Journal of Finance

Chen, C.S., Burton, M., Greenberger, E., Dmitrieva, J., 1999. Population migration and the variation of dopamine D4 receptor (DRD4) allele frequencies around the globe. Evolution and Human Behavior 20, 309-324

Chugh, D., \& Bazerman, M. H. (2007) Bounded Awareness: What you fail to see can hurt you. Mind and Society 6(1), 1-18.

Cohan WD (2009) A Tale of Hubris and Wretched Excess on Wall Street. (Doubleday, New York).

Coates, J.M., Gurnell, M., Rustichini, A., 2009. Second-to-fourth digit ratio predicts success among high-frequency financial traders. Proc Natl Acad Sci U S A 106, 623-8 
Congdon, E., Lesch, K.P., Canli, T., 2008. Analysis of DRD4 and DAT polymorphisms and behavioral inhibition in healthy adults: implications for impulsivity. Am J Med Genet B Neuropsychiatr Genet 147B, 27-32

Crisan, L.G., Pana, S., Vulturar, R., Heilman, R.M., Szekely, R., Druga, B., Dragos, N., Miu, A.C., 2009. Genetic Contributions of the Serotonin Transporter to Social Learning of Fear and Economic Decision Making. Social Cognitive and Affective Neuroscience

Croson, R., Gneezy, U., 2009. Gender Differences in Preferences. Journal of Economic Literature 47, $1-27$

Ding, Y.C., Chi, H.C., Grady, D.L., Morishima, A., Kidd, J.R., Kidd, K.K., Flodman, P., Spence, M.A., Schuck, S., Swanson, J.M., Zhang, Y.P., Moyzis, R.K., 2002. Evidence of positive selection acting at the human dopamine receptor D4 gene locus. Proc Natl Acad Sci U S A 99, 309-14

Dohmen, T.J., Falk, A., Huffman, D., Sunde, U., Schupp, J., Wagner, G.G., Forthcoming. Individual risk attitudes: New evidence from a large, representative, experimentally-validated survey Journal of the European Economic Association

Donkers, B., Melenberg, B., Van Soest, A., 2001. Estimating risk attitudes using lotteries: A large sample approach. Journal of Risk and Uncertainty 22, 165-95

Dreber, A., Apicella, C.L., Eisenberg, D.T.A., Garcia, J.R., Zamore, R.S., Lum, J.K., Campbell, B., 2009. The 7R polymorphism in the dopamine receptor D-4 gene (DRD4) is associated with financial risk taking in men. Evolution and Human Behavior 30, 85-92

Ebstein, R.P., Novick, O., Umansky, R., Priel, B., Osher, Y., Blaine, D., Bennett, E.R., Nemanov, L., Katz, M., Belmaker, R.H., 1996. Dopamine D4 receptor (D4DR) exon III polymorphism associated with the human personality trait of Novelty Seeking. Nat Genet 12, 78-80

Eisenberg, D.T., Campbell, B., Gray, P.B., Sorenson, M.D., 2008. Dopamine receptor genetic polymorphisms and body composition in undernourished pastoralists: An exploration of nutrition indices among nomadic and recently settled Ariaal men of northern Kenya. BMC Evol Biol 8, 173

Eisenberg, D.T., Mackillop, J., Modi, M., Beauchemin, J., Dang, D., Lisman, S.A., Lum, J.K., Wilson, D.S., 2007. Examining impulsivity as an endophenotype using a behavioral approach: a DRD2 TaqI A and DRD4 48-bp VNTR association study. Behav Brain Funct 3, 2

Eisenegger, C., Knoch, D., Ebstein, R.P., Gianotti, L.R., Sandor, P.S., Fehr, E., Dopamine receptor D4 polymorphism predicts the effect of L-DOPA on gambling behavior. Biol Psychiatry 67, 7026

Feigelson, H.S., Rodriguez, C., Robertson, A.S., Jacobs, E.J., Calle, E.E., Reid, Y.A., Thun, M.J., 2001. Determinants of DNA yield and quality from buccal cell samples collected with mouthwash. Cancer Epidemiol Biomarkers Prev 10, 1005-8

Forbes, June 2,1997

Garcia, J.R., MacKillop, J., Aller, E.L., Merriwether, A.M., Wilson, D.S., Lum, J.K., in review. A genetic propensity for infidelity and sexual promiscuity. In: Binghamton University Working Paper.

Gneezy, U., Potters, J., 1997. An Experiment on Risk Taking and Evaluation Periods. Quarterly Journal of Economics 112, 631-645

Guiso, L., Paiella, M., 2005. The Role of Risk Aversion in Predicting Individual Behaviour. In: Chiappori PA \& Gollier C (eds.) Competitive Failures in Insurance Markets: Theory and Policy Implications. CESifo, Monaco.

Halek, M., Eisenhauer, J.G., 2001. Demography of Risk Aversion. The Journal of Risk and Insurance $68,1-24$

Hamer, D., Sirota, L., 2000. Beware the chopsticks gene. Mol Psychiatry 5, 11-3

Hogarth R.M., \& Kunreuther, H. (1995) Decision making under ignorance: arguing with yourself. Journal of Risk and Uncertainty 10, 15-36

Hsee, C.K., Weber, E.U., 1999. Cross-national differences in risk preferences and lay predictions for the differences. Journal of Behavioral Decision Making 12, 165-179

Isaac, R., James, D., 2000. Just Who Are You Calling Risk Averse? Journal of Risk and Uncertainty 20, $177-187$ 
Israel, S., Lerer, E., Shalev, I., Uzefovsky, F., Riebold, M., Laiba, E., Bachner-Melman, R., Maril, A., Bornstein, G., Knafo, A., Ebstein, R.P., 2009. The oxytocin receptor (OXTR) contributes to prosocial fund allocations in the dictator game and the social value orientations task. PLoS ONE 4, e5535

Johnson, E.J., Hershey, J., Meszaros, J., Kunreuther, H. (1993) Framing, probability distortions, and insurance decisions. Journal of Risk and Uncertainty. 7, 35-51

Kahneman, D., Tversky, A., 1979. Prospect Theory: An Analysis of Decision under Risk Econometrica 47, 263-291

Knafo, A., Israel, S., Darvasi, A., Bachner-Melman, R., Uzefovsky, F., Cohen, L., Feldman, E., Lerer, E., Laiba, E., Raz, Y., Nemanov, L., Gritsenko, I., Dina, C., Agam, G., Dean, B., Bornstein, G., Ebstein, R.P., 2007. Individual differences in allocation of funds in the dictator game associated with length of the arginine vasopressin 1a receptor RS3 promoter region and correlation between RS3 length and hippocampal mRNA. Genes, Brain and Behavior 7, 266275

Kuhnen, C.M., Chiao, J.Y., 2009. Genetic determinants of financial risk taking. PLoS One 4, e4362

Laucht, M., Becker, K., Blomeyer, D., Schmidt, M.H., 2007. Novelty seeking involved in mediating the association between the dopamine D4 receptor gene exon III polymorphism and heavy drinking in male adolescents: results from a high-risk community sample. Biol Psychiatry 61, 87-92

Li, D., Sham, P.C., Owen, M.J., He, L., 2006. Meta-analysis shows significant association between dopamine system genes and attention deficit hyperactivity disorder (ADHD). Hum. Mol. Genet. 15, 2276-2284

McDermott, R., Tingley, D., Cowden, J., Frazzetto, G., Johnson, D.D., 2009. Monoamine oxidase A gene (MAOA) predicts behavioral aggression following provocation. Proc Natl Acad Sci U S A 106, 2118-23

Munafo, M.R., Yalcin, B., Willis-Owen, S.A., Flint, J., 2008. Association of the dopamine D4 receptor (DRD4) gene and approach-related personality traits: meta-analysis and new data. Biol Psychiatry 63, 197-206

Perez de Castro, I., Ibanez, A., Torres, P., Saiz-Ruiz, J., Fernandez-Piqueras, J., 1997. Genetic association study between pathological gambling and a functional DNA polymorphism at the D4 receptor gene. Pharmacogenetics. 5, 345- 348

Roe, B.E., Tilley, M.R., Gu, H.H., Beversdorf, D.Q., Sadee, W., al., e., 2009. Financial and Psychological Risk Attitudes Associated with Two Single Nucleotide Polymorphisms in the Nicotine Receptor (CHRNA4) Gene. PLoS ONE 4, e6704

Roiser, J.P., de Martino, B., Tan, G.C., Kumaran, D., Seymour, B., Wood, N.W., Dolan, R.J., 2009. A genetically mediated bias in decision making driven by failure of amygdala control. J Neurosci 29, 5985-91

Sapienza, P., Zingales, L., Maestripieri, D., 2009. Gender differences in financial risk aversion and career choices are affected by testosterone. Proc Natl Acad Sci U S A 106, 15268-73

Schoemaker, P.J.H., 1993. Determinants of risk-taking: Behavioral and economic views. Journal of Risk and Uncertainty 6, 49-73

Schoots, O., Van Tol, H.H.M., 2003. The human dopamine D4 receptor repeat sequences modulate expression. he Pharmacogenomics Journal 3, 343-348

Slovic, P., 1964. Assessment of risk taking behavior. Psychological Bulletin 61, 220-233

Wallace, B., Cesarini, D., Lichtenstein, P., Johannesson, M., 2007. Heritability of ultimatum game responder behavior. Proc Natl Acad Sci U S A 104, 15631-4

Zethraeus, N., Kocoska-Maras, L., Ellingsen, T., von Schoultz, B., Hirschberg, A.L., Johannesson, M., 2009. A randomized trial of the effect of estrogen and testosterone on economic behavior. Proc Natl Acad Sci U S A

Zhong, S., Chew, S.H., Set, E., Zhang, J., Israel, S., Xue, H., Sham, P.C., Ebstein, R.P., 2009a. The Heritability of Attitude Toward Economic Risk. Twin Research and Human Genetics 12, 103107

Zhong, S., Israel, S., Xue, H., Ebstein, R.P., Chew, S.H., 2009b. Monoamine Oxidase A Gene (MAOA) Associated with Attitude Towards Longshot Risks. PLoS ONE 4, e8516 
Zhong, S., Israel, S., Xue, H., Sham, P.C., Ebstein, R.P., Chew, S.H., 2009c. A neurochemical approach to valuation sensitivity over gains and losses. Proc Biol Sci 276, 4181-8 


\section{Appendix 1}

\section{Background on DRD4}

The human DRD4 gene on chromosome 11 contains a 48bp variable number tandem repeat (VNTR) polymorphism (variation) in exon 3 and consists of 2-11 repeats (Ding et al. 2002), likely involved in modulating expression of the gene (Schoots and Van Tol 2003). There is generally a trimodal distribution of 2, 4 and 7 repeat alleles (2R, 4R and $7 R$ ) in most populations (Ding et al. 2002).

\section{Genotyping}

Genotyping was performed at the Laboratory of Evolutionary Anthropology and Health at Binghamton University, New York. Each participant was given a 15ml centrifuge tube containing approximately $10 \mathrm{ml}$ of Scope ${ }^{\circledR}$ mouthwash (Feigelson et al. 2001). Participants gently swirled the mouthwash from cheek to cheek for 45 seconds, to collect buccal cells. Using a sterile straw, participants were instructed to spit the sample back into the same centrifuge tube. Samples were later centrifuged and prepared for DNA extraction using the Maxwell $^{\circledR} 16$ System (Promega).

Sufficient DNA for DRD4 PCR amplification was extracted from 86\% (203/237) of the buccal cell samples. Genotyping was only performed for the one candidate gene $D R D 4$. Previous studies have highlighted problems associated with consistent genotyping of the DRD4 VNTR region (Eisenberg et al. 2008), suggesting multiple PCR runs for each sample to control for allelic dropout. Thus, the PCR reaction was modified to reflect the high GC content (see below) and all samples that were initially scored as homozygotes were reanalyzed two additional times with different starting template concentrations to confirm genotypes. The PCR reaction consisted of 1x Q-Solution (Qiagen), 1x Buffer (Qiagen), $1 \mu \mathrm{M}$ Primer 1 (5’ GCGACTACGTGGTCTACTCG $\quad$ 3’), $1 \mu \mu$ Primer 2 (5' AGGACCCTCATGGCCTTG 3'), $200 \mu \mathrm{M}$ dATP, $200 \mu \mathrm{M}$ dTTP, $200 \mu \mathrm{M}$ dCTP, $100 \mu \mathrm{M}$ dITP, $100 \mu \mathrm{M}$ dGTP, 0.3 units HotStar Taq (Qiagen), and $1 \mu \mathrm{l}$ of DNA template, in a total volume of $10 \mu \mathrm{l}$. The PCR profile began with 15 minutes at $95^{\circ} \mathrm{C}$ for enzyme activation and denaturing of template DNA followed by 40 cycles consisting of 1 minute denaturation at $94^{\circ} \mathrm{C}, 1$ minute annealing at $55^{\circ} \mathrm{C}, 1.5$ minute extension at $72^{\circ} \mathrm{C}$, and finished with a 10 minute extension at $72^{\circ} \mathrm{C}$. Amplicons were electrophoresed through $1.4-2.0 \%$ agarose gels containing ethidium bromide and genotypes were determined by comparison with a $100 \mathrm{bp}$ ladder. Participants were then scored as either $7 \mathrm{R}+$ (at least one allele of at least 7-repeats or more) or 7R- (both alleles less than 7-repeats).

Population stratification can be an issue in this type of candidate gene study (see Hamer and Sirota 2000). Population stratification in this case could lead to biased results due to allele frequency similarities amongst subpopulations with homogenous ancestry. In the sample studied here, an overwhelming majority of participants self-reported Caucasian race, hence we believe these legitimate concerns to be minimal for our particular results. 


\section{Appendix 2}

Table A1. Summary statistics for genotyped participants.

\begin{tabular}{|c|c|c|c|}
\hline Variable & All & Men & Women \\
\hline $7 \mathrm{R}+$ & $\begin{array}{l}\mathrm{N}=203, \mathrm{M}=0.13 \\
\mathrm{SD}=0.34\end{array}$ & $\begin{array}{l}\mathrm{N}=105, \mathrm{M}=0.18 \\
\mathrm{SD}=0.39\end{array}$ & $\begin{array}{l}\mathrm{N}=85, \mathrm{M}=0.07 \\
\mathrm{SD}=0.26\end{array}$ \\
\hline $\begin{array}{l}\text { Overall bridge risk (0 to } \\
\text { 8) }\end{array}$ & $\begin{array}{l}\mathrm{N}=197, \mathrm{M}=3.82, \\
\mathrm{SD}=1.31\end{array}$ & $\begin{array}{l}\mathrm{N}=103, \mathrm{M}=3.69 \\
\mathrm{SD}=1.26\end{array}$ & $\begin{array}{l}\mathrm{N}=82, \mathrm{M}=3.96 \\
\mathrm{SD}=1.39\end{array}$ \\
\hline Good bridge risk & $\begin{array}{l}\mathrm{N}=191, \mathrm{M}=12.41, \\
\mathrm{SD}=8.12\end{array}$ & $\begin{array}{l}\mathrm{N}=101, \mathrm{M}=12.19, \\
\mathrm{SD}=7.90\end{array}$ & $\begin{array}{l}\mathrm{N}=80, \mathrm{M}=12.37 \\
\mathrm{SD}=8.33\end{array}$ \\
\hline Bad bridge risk & $\begin{array}{l}N=191, M=33.15 \\
S D=27.37\end{array}$ & $\begin{array}{l}\mathrm{N}=101, \mathrm{M}=33.16, \\
\mathrm{SD}=27.47\end{array}$ & $\begin{array}{l}\mathrm{N}=80, \mathrm{M}=33.98 \\
\mathrm{SD}=28.20\end{array}$ \\
\hline Masterpoints & $\begin{array}{l}\mathrm{N}=197, \mathrm{M}=3133.7 \\
\mathrm{SD}=4210.7\end{array}$ & $\begin{array}{l}\mathrm{N}=101, \mathrm{M}=4138.1, \\
\mathrm{SD}=4707.8\end{array}$ & $\begin{array}{l}\mathrm{N}=83, \mathrm{M}=1796.9, \\
\mathrm{SD}=2776.1\end{array}$ \\
\hline $\begin{array}{l}\mathrm{L}_{10} \mathrm{MP} \\
{[\log 10(\text { masterpoints }+1)]}\end{array}$ & $\begin{array}{l}\mathrm{N}=197, \mathrm{M}=3.04, \\
\mathrm{SD}=0.79\end{array}$ & $\begin{array}{l}\mathrm{N}=105, \mathrm{M}=3.27, \\
\mathrm{SD}=0.69\end{array}$ & $\begin{array}{l}\mathrm{N}=83, \mathrm{M}=2.75 \\
\mathrm{SD}=0.84\end{array}$ \\
\hline Economic risk (0 to 250 ) & $\begin{array}{l}\mathrm{N}=199, \mathrm{M}=164.4, \\
\mathrm{SD}=91.2\end{array}$ & $\begin{array}{l}\mathrm{N}=105, \mathrm{M}=198.8, \\
\mathrm{SD}=79.7\end{array}$ & $\begin{array}{l}\mathrm{N}=81, \mathrm{M}=120.1, \\
\mathrm{SD}=88.8\end{array}$ \\
\hline Risk perception (0 to 10$)$ & $\begin{array}{l}\mathrm{N}=186, \mathrm{M}=6.31 \\
\mathrm{SD}=2.27\end{array}$ & $\begin{array}{l}\mathrm{N}=97, \mathrm{M}=6.84, \\
\mathrm{SD}=2.26\end{array}$ & $\begin{array}{l}\mathrm{N}=79, \mathrm{M}=5.66 \\
\mathrm{SD}=2.20\end{array}$ \\
\hline Stocks (11 categories) & $\begin{array}{l}\mathrm{N}=180, \mathrm{M}=4.65, \\
\mathrm{SD}=2.83\end{array}$ & $\begin{array}{l}\mathrm{N}=98, \mathrm{M}=4.84, \\
\mathrm{SD}=3.01\end{array}$ & $\begin{array}{l}\mathrm{N}=72, \mathrm{M}=4.22, \\
\mathrm{SD}=2.60\end{array}$ \\
\hline Bonds (11 categories) & $\begin{array}{l}\mathrm{N}=173, \mathrm{M}=2.22 \\
\mathrm{SD}=1.76\end{array}$ & $\begin{array}{l}\mathrm{N}=96, \mathrm{M}=2.02, \\
\mathrm{SD}=1.78\end{array}$ & $\begin{array}{l}\mathrm{N}=68, \mathrm{M}=2.56, \\
\mathrm{SD}=1.78\end{array}$ \\
\hline $\begin{array}{l}\text { Started company (yes }=1 \text {, } \\
\text { no }=0 \text { ) }\end{array}$ & $\begin{array}{l}\mathrm{N}=198, \mathrm{M}=0.62, \\
\mathrm{SD}=0.49\end{array}$ & $\begin{array}{l}\mathrm{N}=103, \mathrm{M}=0.60, \\
\mathrm{SD}=0.49\end{array}$ & $\begin{array}{l}\mathrm{N}=84, \mathrm{M}=0.64 \\
\mathrm{SD}=0.48\end{array}$ \\
\hline $\begin{array}{l}\text { Cigarette consumption } \\
\text { (packages/month) }\end{array}$ & $\begin{array}{l}\mathrm{N}=181, \mathrm{M}=1.33 \\
\mathrm{SD}=21.56^{*}\end{array}$ & $\begin{array}{l}\mathrm{N}=99, \mathrm{M}=1.16 \\
\mathrm{SD}=23.81^{*}\end{array}$ & $\begin{array}{l}\mathrm{N}=73, \mathrm{M}=1.71 \\
\mathrm{SD}=21.73^{*}\end{array}$ \\
\hline $\begin{array}{l}\text { Alcohol consumption } \\
\text { (drinks/month) }\end{array}$ & $\begin{array}{l}\mathrm{N}=196, \mathrm{M}=19.53, \\
\mathrm{SD}=35.36^{*}\end{array}$ & $\begin{array}{l}\mathrm{N}=101, \mathrm{M}=24.2, \\
\mathrm{SD}=41.80^{*}\end{array}$ & $\begin{array}{l}\mathrm{N}=84, \mathrm{M}=14.7 \\
\mathrm{SD}=25.69 *\end{array}$ \\
\hline Age (9 categories) & $\begin{array}{l}\mathrm{N}=199, \mathrm{M}=5.36, \\
\mathrm{SD}=1.34\end{array}$ & $\begin{array}{l}\mathrm{N}=103, \mathrm{M}=4.98, \\
\mathrm{SD}=1.35\end{array}$ & $\begin{array}{l}\mathrm{N}=85, \mathrm{M}=5.83 \\
\mathrm{SD}=1.19\end{array}$ \\
\hline $\begin{array}{l}\text { Sexual orientation }(1= \\
\text { hetero, } 0=\text { other })\end{array}$ & $\begin{array}{l}\mathrm{N}=203, \mathrm{M}=0.91 \\
\mathrm{SD}=0.28\end{array}$ & $\begin{array}{l}\mathrm{N}=105, \mathrm{M}=0.94 \\
\mathrm{SD}=0.23\end{array}$ & $\begin{array}{l}\mathrm{N}=85, \mathrm{M}=0.92 \\
\mathrm{SD}=0.28\end{array}$ \\
\hline $\begin{array}{l}\text { Marital status (4 } \\
\text { categories) }\end{array}$ & $\mathrm{N}=197, \mathrm{M}=2.08$ & $\mathrm{~N}=103, \mathrm{M}=1.94$ & $\mathrm{~N}=83, \mathrm{M}=2.28$ \\
\hline Height in $\mathrm{cm}$. & $\begin{array}{l}\mathrm{N}=190, \mathrm{M}=173.4, \\
\mathrm{SD}=28.7\end{array}$ & $\begin{array}{l}\mathrm{N}=97, \mathrm{M}=182.2 \\
\mathrm{SD}=137.6\end{array}$ & $\begin{array}{l}\mathrm{N}=82, \mathrm{M}=164.2 \\
\mathrm{SD}=7.00\end{array}$ \\
\hline
\end{tabular}

*The reported standard deviations are for those that smoke or drink alcohol. 
Table A2. Correlation matrix for overall bridge risk taking, good bridge risk taking, bad bridge risk taking, economic risk taking, investments in stocks and bonds, entrepreneurship, smoker, drinker. Men only.

\begin{tabular}{|c|c|c|c|c|c|c|c|c|c|}
\hline Men & Overall & Good & Bad & Econ & Gen $r$ & SB & Entr & Smo & Drink \\
\hline Overall bridge & 1.0000 & & & & & & & & \\
\hline Good bridge & 0.1290 & 1.0000 & & & & & & & \\
\hline Bad bridge & $\begin{array}{c}0.6105 \\
* * *\end{array}$ & $\begin{array}{c}-0.3449 \\
* * *\end{array}$ & 1.0000 & & & & & & \\
\hline Econ risk & 0.0055 & 0.0843 & -0.0029 & 1.0000 & & & & & \\
\hline Gen risk & 0.0191 & -0.0308 & 0.0055 & $\underset{* *}{0.1871}$ & 1.0000 & & & & \\
\hline StocksBonds ${ }^{a}$ & 0.0565 & 0.1069 & -0.0175 & 0.1585 & 0.1056 & 1.0000 & & & \\
\hline Entrepreneur & 0.1020 & 0.1250 & 0.0567 & -0.0721 & $\begin{array}{c}-0.2535 \\
* * *\end{array}$ & -0.0794 & 1.0000 & & \\
\hline Smoker & -0.0865 & -0.0110 & -0.0179 & -0.0780 & -0.0440 & 0.0932 & $0.1670^{*}$ & 1.0000 & \\
\hline Drinker & -0.0161 & 0.1244 & -0.0393 & 0.1436 & $0.1769 *$ & 0.0663 & -0.0425 & 0.1428 & 1.0000 \\
\hline
\end{tabular}

Table A3. Correlation matrix for overall bridge risk taking, good bridge risk taking, bad bridge risk taking, economic risk taking, investments in stocks and bonds, entrepreneurship, smoker, drinker. Women only.

\begin{tabular}{|c|c|c|c|c|c|c|c|c|c|}
\hline Women & Overall & Good & Bad & Econ & Gen $r$ & SB & Entr & Smo & Drink \\
\hline Overall bridge & 1.0000 & & & & & & & & \\
\hline Good bridge & $\begin{array}{c}0.3623 \\
* * *\end{array}$ & 1.0000 & & & & & & & \\
\hline Bad bridge & $\begin{array}{c}0.5334 \\
* * *\end{array}$ & $\begin{array}{c}-0.2524 \\
* *\end{array}$ & 1.0000 & & & & & & \\
\hline Econ risk & 0.0392 & 0.0644 & 0.0073 & 1.0000 & & & & & \\
\hline Gen risk & 0.1190 & -0.0422 & 0.1685 & $\begin{array}{c}0.2566 \\
* *\end{array}$ & 1.0000 & & & & \\
\hline StocksBonds & 0.1045 & 0.1592 & -0.0725 & 0.1114 & 0.1018 & 1.0000 & & & \\
\hline Entrepreneur & $\underset{* *}{0.2114}$ & $\begin{array}{c}0.2035 \\
* *\end{array}$ & 0.0133 & -0.1114 & 0.1132 & -0.1374 & 1.0000 & & \\
\hline Smoker & 0.1361 & -0.0656 & 0.0212 & 0.0305 & -0.0801 & 0.0856 & -0.1168 & 1.0000 & \\
\hline Drinker & 0.0342 & 0.0198 & -0.1113 & 0.0171 & -0.0576 & $\begin{array}{c}0.2282 \\
* *\end{array}$ & -0.0382 & 0.0661 & 1.0000 \\
\hline
\end{tabular}

${ }^{\text {a }}$ StocksBonds is an abbreviation for stocks/(stocks+bonds) throughout. 
Table A4. Overall bridge risk taking. All observations (columns 1-3), men only (columns 45), women only (columns 6-7).

\begin{tabular}{|c|c|c|c|c|c|c|c|}
\hline & \multicolumn{3}{|c|}{ All observations } & \multicolumn{2}{|c|}{ Men } & \multicolumn{2}{|c|}{ Women } \\
\hline & (1) & (2) & (3) & (4) & (5) & (6) & (7) \\
\hline & Overall & Overall & Overall & Overall & Overall & Overall & Overall \\
\hline \multirow[t]{2}{*}{$7 \mathbf{R}+$} & 0.019 & 0.199 & 0.545 & 0.248 & 0.519 & -0.723 & -0.631 \\
\hline & $(0.08)$ & $(0.69)$ & $(1.74)^{*}$ & $(0.83)$ & $(1.67)^{*}$ & $(1.44)$ & $(1.14)$ \\
\hline \multirow[t]{2}{*}{ Female } & & 0.044 & 0.149 & & & & \\
\hline & & $(0.18)$ & (0.59) & & & & \\
\hline \multirow[t]{2}{*}{ Age } & & 0.140 & 0.143 & & 0.041 & & 0.233 \\
\hline & & (1.44) & (1.47) & & $(0.32)$ & & (1.57) \\
\hline \multirow[t]{2}{*}{ Height } & & -0.003 & -0.003 & & -0.002 & & -0.047 \\
\hline & & (1.48) & (1.38) & & $(0.97)$ & & $(2.73) * * *$ \\
\hline \multirow[t]{2}{*}{$\mathrm{L}_{10} \mathrm{MP}$} & & 0.119 & 0.104 & & 0.236 & & -0.013 \\
\hline & & $(0.92)$ & $(0.82)$ & & (1.35) & & $(0.07)$ \\
\hline \multirow[t]{2}{*}{$7 R+x$ Female } & & & -1.090 & & & & \\
\hline & & & $(1.86)^{*}$ & & & & \\
\hline \multirow[t]{2}{*}{ Constant } & 3.817 & 3.186 & 3.138 & 3.651 & 2.992 & 4.010 & 10.362 \\
\hline & $(37.25)^{* * *}$ & $(4.61) * * *$ & $(4.58) * * *$ & $(26.08)^{* * *}$ & $(3.82) * * *$ & $(24.89)^{* * *}$ & $(3.23) * * *$ \\
\hline Observations & 197 & 169 & 169 & 103 & 92 & 82 & 77 \\
\hline $\mathbf{R}^{2}$ & 0.00 & 0.03 & 0.05 & 0.01 & 0.04 & 0.02 & 0.14 \\
\hline \multicolumn{8}{|c|}{ Robust $\mathbf{t}$ statistics in parentheses } \\
\hline
\end{tabular}

Table A5. Good risk and bad risk taking in bridge. All observations.

\begin{tabular}{|c|c|c|c|c|c|c|}
\hline & (1) & (2) & (3) & (4) & (5) & (6) \\
\hline & Good & Good & Good & Bad & $\mathrm{Bad}$ & Bad \\
\hline \multirow[t]{2}{*}{$\overline{7 R+}$} & 1.095 & 1.744 & 1.617 & -2.015 & -1.146 & 4.051 \\
\hline & $(0.53)$ & $(0.78)$ & $(0.59)$ & $(0.35)$ & $(0.17)$ & $(0.43)$ \\
\hline \multirow[t]{2}{*}{ Female } & & 0.458 & 0.418 & & -2.131 & -0.517 \\
\hline & & $(0.32)$ & $(0.29)$ & & $(0.48)$ & $(0.11)$ \\
\hline \multirow[t]{2}{*}{ Age } & & 0.143 & 0.142 & & 1.391 & 1.417 \\
\hline & & $(0.29)$ & $(0.28)$ & & $(0.74)$ & $(0.75)$ \\
\hline \multirow[t]{2}{*}{ Height } & & 0.017 & 0.017 & & -0.054 & -0.051 \\
\hline & & $(0.72)$ & $(0.71)$ & & $(1.20)$ & $(1.13)$ \\
\hline \multirow[t]{2}{*}{$\mathrm{L}_{10} \mathrm{MP}$} & & 0.771 & 0.778 & & -0.457 & -0.720 \\
\hline & & $(0.91)$ & $(0.92)$ & & $(0.18)$ & $(0.28)$ \\
\hline \multirow[t]{2}{*}{ 7R+ x Female } & & & 0.403 & & & -16.388 \\
\hline & & & $(0.09)$ & & & (1.29) \\
\hline \multirow[t]{2}{*}{ Constant } & 12.264 & 5.835 & 5.849 & 33.429 & 37.863 & 37.267 \\
\hline & $(20.21)^{* * *}$ & $(0.99)$ & $(0.99)$ & $(15.64)^{* * *}$ & $(2.78) * * *$ & $(2.76)^{* * *}$ \\
\hline Observations & 191 & 165 & 165 & 191 & 165 & 165 \\
\hline $\mathbf{R}^{2}$ & 0.00 & 0.01 & 0.01 & 0.00 & 0.01 & 0.01 \\
\hline
\end{tabular}


Table A6. Good risk and bad risk taking in bridge, interactions between 7R+, masterpoints (LMP) and being female. All observations (columns 1-2, 5-6), men only (columns 3, 7), women only (columns 4, 8).

\begin{tabular}{|c|c|c|c|c|c|c|c|c|}
\hline & \multicolumn{2}{|c|}{ All observations } & \multirow{2}{*}{$\begin{array}{l}\text { Men } \\
\text { (3) }\end{array}$} & \multirow{2}{*}{$\begin{array}{l}\text { Women } \\
(4)\end{array}$} & \multicolumn{2}{|c|}{ All observations } & \multirow{2}{*}{$\begin{array}{l}\text { Men } \\
\text { (7) }\end{array}$} & \multirow{2}{*}{\begin{tabular}{|l|} 
Women \\
$(8)$
\end{tabular}} \\
\hline & (1) & (2) & & & (5) & (6) & & \\
\hline & Good & Good & Good & Good & $\mathrm{Bad}$ & $\mathrm{Bad}$ & Bad & $\mathrm{Bad}$ \\
\hline \multirow[t]{2}{*}{$7 \mathbf{R}+$} & -5.366 & -29.290 & -32.184 & 7.308 & 20.713 & 107.666 & 102.805 & -11.643 \\
\hline & $(0.55)$ & $(3.02) * * *$ & $(3.58) * * *$ & (1.37) & $(0.81)$ & $(2.40)^{* *}$ & $(2.27)^{* *}$ & $(0.85)$ \\
\hline \multirow{2}{*}{ Female } & 0.535 & 2.141 & & & -2.368 & 16.512 & & \\
\hline & $(0.38)$ & $(0.37)$ & & & $(0.53)$ & $(1.00)$ & & \\
\hline \multirow[t]{2}{*}{ Age } & 0.070 & -0.085 & -0.873 & 1.077 & 1.616 & 2.162 & 0.640 & 3.137 \\
\hline & $(0.14)$ & $(0.17)$ & (1.48) & (1.06) & $(0.87)$ & (1.14) & $(0.30)$ & (1.07) \\
\hline \multirow{2}{*}{ Height } & 0.017 & 0.013 & 0.013 & 0.016 & -0.054 & -0.040 & -0.017 & -0.950 \\
\hline & $(0.74)$ & $(0.56)$ & (0.59) & (0.13) & $(1.23)$ & (1.08) & $(0.60)$ & $(2.15)^{* *}$ \\
\hline \multirow[t]{2}{*}{$\mathrm{L}_{10} \mathrm{MP}$} & 0.390 & 0.671 & 0.831 & -0.199 & 0.716 & 3.747 & 4.034 & -1.738 \\
\hline & $(0.43)$ & $(0.61)$ & $(0.77)$ & $(0.14)$ & $(0.26)$ & $(1.02)$ & $(1.05)$ & $(0.43)$ \\
\hline \multirow{2}{*}{$7 \mathrm{R}+\mathrm{x} \mathrm{L}_{10} \mathrm{MP}$} & 2.391 & 9.659 & 10.462 & -2.209 & -7.350 & -32.311 & -30.931 & -0.892 \\
\hline & $(0.77)$ & $(3.30)^{* * *}$ & $(3.80)^{* * *}$ & (1.06) & (0.99) & $(2.49) * *$ & $(2.37)^{* *}$ & $(0.17)$ \\
\hline \multirow[t]{2}{*}{$7 R+x$ Female } & & 35.407 & & & & -126.333 & & \\
\hline & & $(3.22) * * *$ & & & & $(2.69) * * *$ & & \\
\hline \multirow{2}{*}{ Female $x L_{10} M P$} & & -0.592 & & & & -5.496 & & \\
\hline & & $(0.32)$ & & & & (1.03) & & \\
\hline \multirow[t]{2}{*}{$\begin{array}{l}7 \mathrm{R}+\mathrm{x} \text { Female } \mathrm{x} \\
\mathrm{L}_{10} \mathrm{MP}\end{array}$} & & -11.550 & & & & 34.931 & & \\
\hline & & $(3.26) * * *$ & & & & $(2.53)^{* *}$ & & \\
\hline \multirow[t]{2}{*}{ Constant } & 7.361 & 8.122 & 11.495 & 3.752 & 33.171 & 17.088 & 19.441 & 177.601 \\
\hline & (1.24) & (1.26) & (1.74)* & $(0.16)$ & $(2.50)^{* *}$ & (1.18) & (1.34) & $(2.55)^{* *}$ \\
\hline Observations & 165 & 165 & 90 & 75 & 165 & 165 & 90 & 75 \\
\hline $\mathbf{R}^{2}$ & 0.02 & 0.07 & 0.15 & 0.03 & 0.01 & 0.06 & 0.07 & 0.10 \\
\hline
\end{tabular}


Table A7. Economic risk taking. All observations (columns 1-3), men only (columns 4-5), women only (columns 6-7).

\begin{tabular}{|c|c|c|c|c|c|c|c|}
\hline & \multicolumn{3}{|c|}{ All observations } & \multicolumn{2}{|c|}{ Men } & \multicolumn{2}{|c|}{ Women } \\
\hline & \multirow{2}{*}{$\begin{array}{l}\text { (1) } \\
\text { Econ risk }\end{array}$} & \multirow{2}{*}{$\begin{array}{l}\text { (2) } \\
\text { Econ risk }\end{array}$} & \multirow{2}{*}{$\begin{array}{l}\text { (3) } \\
\text { Econ risk }\end{array}$} & \multirow{2}{*}{$\begin{array}{l}\text { (4) } \\
\text { Econ risk }\end{array}$} & \multirow{2}{*}{$\begin{array}{l}\text { (5) } \\
\text { Econ risk }\end{array}$} & \multicolumn{2}{|c|}{ (6) (7) } \\
\hline & & & & & & Econ risk & Econ risk \\
\hline \multirow{2}{*}{$7 \mathrm{R}+$} & 20.820 & 19.730 & 40.363 & 28.729 & 39.190 & -26.233 & -28.021 \\
\hline & $(1.12)$ & (1.34) & $(3.09) * * *$ & $(1.76)^{*}$ & $(2.99) * * *$ & $(0.76)$ & $(0.81)$ \\
\hline \multirow{2}{*}{ Female } & & -70.201 & -62.619 & & & & \\
\hline & & $(4.89) * * *$ & $(4.13) * * *$ & & & & \\
\hline \multirow[t]{2}{*}{ Age } & & -9.873 & -9.983 & & -13.297 & & -5.232 \\
\hline & & $(2.22)^{* *}$ & $(2.25)^{* *}$ & & $(2.54)^{* *}$ & & $(0.63)$ \\
\hline \multirow[t]{2}{*}{ Height } & & 0.125 & 0.140 & & 0.153 & & -0.261 \\
\hline & & (1.11) & $(1.23)$ & & $(1.32)$ & & $(0.16)$ \\
\hline \multirow[t]{2}{*}{ 7R+ x Female } & & & -70.244 & & & & \\
\hline & & & $(1.98)^{* *}$ & & & & \\
\hline \multirow[t]{2}{*}{ Constant } & 161.587 & 224.355 & 218.841 & 193.640 & 233.116 & 122.067 & 194.132 \\
\hline & $(23.19)^{* * *}$ & $(7.73)^{* * *}$ & $(7.51)^{* * *}$ & $(21.62)^{* * *}$ & $(7.80) * * *$ & $(11.78)^{* * *}$ & $(0.68)$ \\
\hline Observations & 199 & 175 & 175 & 105 & 97 & 81 & 78 \\
\hline $\mathbf{R}^{2}$ & 0.01 & 0.23 & 0.24 & 0.02 & 0.10 & 0.01 & 0.01 \\
\hline
\end{tabular}

Table A8. General risk taking. All observations.

\begin{tabular}{|c|c|c|c|}
\hline & (1) & $(2)$ & (3) \\
\hline & risk & risk & Risk \\
\hline \multirow[t]{2}{*}{$7 \mathrm{R}+$} & -0.012 & -0.393 & -0.464 \\
\hline & $(0.02)$ & $(0.65)$ & (0.59) \\
\hline \multirow[t]{2}{*}{ Female } & & -1.237 & -1.262 \\
\hline & & $(3.22) * * *$ & $(3.10)^{* * *}$ \\
\hline \multirow[t]{2}{*}{ Age } & & -0.039 & -0.038 \\
\hline & & $(0.27)$ & $(0.27)$ \\
\hline \multirow[t]{2}{*}{ Height } & & -0.000 & -0.001 \\
\hline & & $(0.14)$ & $(0.15)$ \\
\hline \multirow[t]{2}{*}{ 7R+ $x$ Female } & & & 0.253 \\
\hline & & & $(0.23)$ \\
\hline \multirow[t]{2}{*}{ Constant } & 6.316 & 7.141 & 7.158 \\
\hline & $(35.71)^{* * *}$ & $(6.58) * * *$ & $(6.53) * * *$ \\
\hline Observations & 186 & 167 & 167 \\
\hline $\mathbf{R}^{2}$ & 0.00 & 0.07 & 0.07 \\
\hline
\end{tabular}


Table A9. Investments in stocks and bonds, entrepreneurship. All observations.

\begin{tabular}{|c|c|c|c|c|c|c|}
\hline & (1) & (2) & (3) & (4) & (5) & (6) \\
\hline & StocksBonds & StocksBonds & StocksBonds & Entrep & Entrep & Entrep \\
\hline \multirow[t]{2}{*}{$7 \mathrm{R}+$} & -0.030 & -0.037 & -0.024 & -0.028 & 0.169 & -0.172 \\
\hline & $(0.85)$ & $(1.05)$ & $(0.53)$ & $(0.07)$ & $(0.35)$ & $(0.31)$ \\
\hline \multirow[t]{2}{*}{ Female } & & -0.071 & -0.066 & & 0.043 & -0.084 \\
\hline & & $(2.60)^{* *}$ & $(2.23)^{* *}$ & & $(0.12)$ & $(0.23)$ \\
\hline \multirow[t]{2}{*}{ Age } & & 0.006 & 0.005 & & 0.186 & 0.189 \\
\hline & & $(0.58)$ & $(0.53)$ & & $(1.48)$ & $(1.53)$ \\
\hline \multirow[t]{2}{*}{ Height } & & 0.001 & 0.001 & & 0.006 & 0.005 \\
\hline & & $(4.06) * * *$ & $(4.07)^{* * *}$ & & $(1.28)$ & $(1.22)$ \\
\hline \multirow[t]{2}{*}{ 7R+ x Female } & & & -0.054 & & & 1.379 \\
\hline & & & $(0.82)$ & & & (1.08) \\
\hline \multirow[t]{2}{*}{ Constant } & 0.627 & 0.503 & 0.502 & 0.498 & -1.458 & -1.371 \\
\hline & $(48.82)^{* * *}$ & $(8.13) * * *$ & $(8.10)^{* * * *}$ & $(3.16)^{* * *}$ & (1.39) & $(1.32)$ \\
\hline Observations & 160 & 145 & 145 & 198 & 178 & 178 \\
\hline $\mathbf{R}^{2}$ / Pseudo $\mathbf{R}^{2}$ & 0.00 & 0.09 & 0.09 & 0.00 & 0.01 & 0.02 \\
\hline
\end{tabular}

Table A10. Smoker, drinker. All observations.

\begin{tabular}{|l|l|l|l|l|l|}
\hline & $\mathbf{( 1 )}$ & $\mathbf{( 2 )}$ & $\mathbf{( 3 )}$ & $\mathbf{( 4 )}$ & $\mathbf{( 5 )}$ \\
\hline & Smoker & Smoker & Drinker & Drinker & Drinker \\
\hline 7R+ & -0.983 & -1.030 & -0.022 & -0.153 & 0.006 \\
& $(1.29)$ & $(0.95)$ & $(0.04)$ & $(0.25)$ & $(0.01)$ \\
Female & & 0.440 & & -0.536 & -0.489 \\
& & $(0.90)$ & & $(1.06)$ & $(0.93)$ \\
Height & & 0.342 & & -0.000 & 0.001 \\
& & $(1.83)^{*}$ & & $(0.00)$ & $(0.01)$ \\
7R+ x Female & & -0.006 & & 0.040 & 0.040 \\
& & $(0.79)$ & & $(1.86)^{*}$ & $(1.86)^{*}$ \\
Constant & -1.543 & -2.945 & 1.504 & -4.873 & -4.946 \\
& $(7.78)^{* * *}$ & $(1.77)^{*}$ & $(7.68)^{* * *}$ & $(1.22)$ & $(1.23)$ \\
Observations & 203 & 179 & 203 & 179 & 179 \\
Pseudo R ${ }^{2}$ & 0.01 & 0.06 & 0.00 & 0.06 & 0.06 \\
Robust t statistics in parentheses \\
* significant at 10\%; $*$ significant at 5\%; *** significant at 1\%
\end{tabular}




\section{Appendix 3}

Note to referees: In any published version, the bridge quiz and scores will be made available online. Depending on recommendation of referees and editors, question 1 and its scores may be published as a sample.

\section{Bridge Quiz}

You have 10 minutes to complete the following questions. Please do not discuss the questions with anyone while you are taking the quiz or indeed until the answers are posted on our website at midnight Tuesday the 25th. We will distribute hard copies of the answers on Wednesday the 26th. Finally, we are not available to provide any further information; you are on your own. Good luck!

1) Imps: N-S vul. You, South, hold:

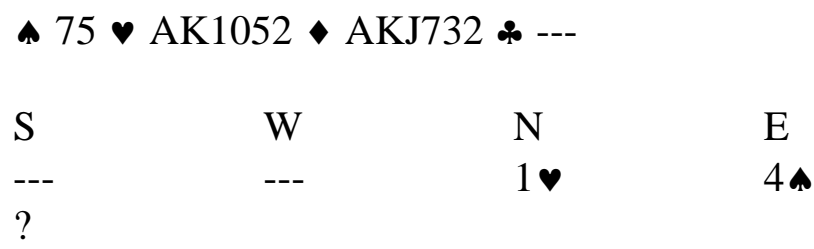
A) Which of the following choices do you prefer?
i) $\quad 6 \bullet$
ii) $5 \vee$
iii) Other
B) Which of the above choices do you least prefer?

2) Matchpoints; N-South vul. You, South, hold:

^ $\mathrm{Q} 62$ • 4 • 92 A 1087432

$\begin{array}{llll}\text { S } & \text { W } & \text { N } & \text { E }\end{array}$

?

Which of the following choices do you prefer?
i) 3\%
ii) Pass 
3) Imps; Love All. You, South, hold:

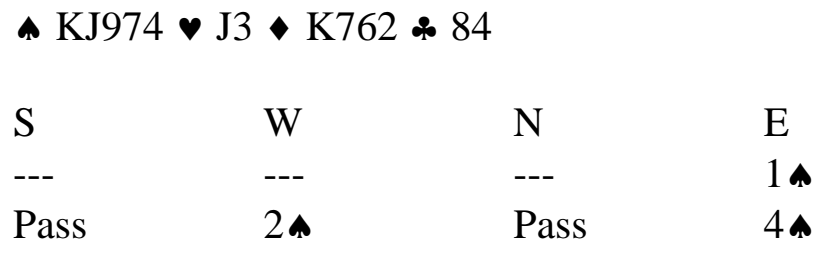

?

Which of the following choices do you prefer?

$\begin{array}{ll}\text { i) } & \text { Pass } \\ \text { ii) } & \text { Double }\end{array}$

4) Imps; Love All. You, South, hold:

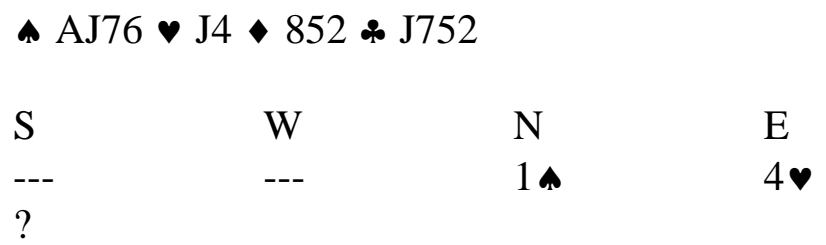

Which of the following choices do you prefer?

i) Pass

ii) 4a 
5) Imps; N-S vul. You, South, hold:

^ $\mathrm{Q} 108 \bullet \mathrm{Q} 74$ A2 * AK1075

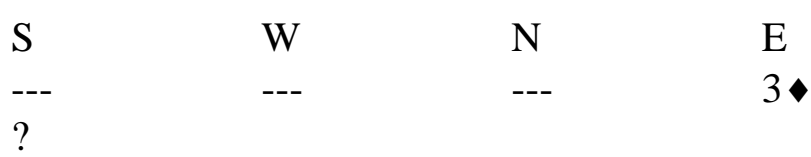
A) Which of the following choices do you prefer?
i) Double
ii) Pass
iii) $\quad 3 \mathrm{~N}$

A) Which of the above choices do you least prefer?

6) Matchpoints; Both vul. You, South, hold:

^ 842 • 1052 • 93 AKQ109

$\begin{array}{llll}\text { S } & \text { W } & \text { N } & \text { E } \\ -- & 1 * & \text { Pass } & 2 N^{*} \\ \text { Pass } & 3 \mathrm{~N} & \text { Pass } & \text { Pass }\end{array}$

?

*Forcing

Which of the following choices do you prefer?

i) Double

ii) Pass 
7) Imps; E-W Vul. You, South, hold:

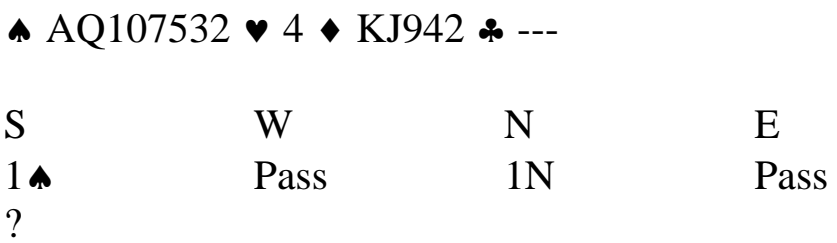
A) Which of the following choices do you prefer?
i) 2 •
ii) 3
iii) $\quad 4 \boldsymbol{s}$
iv) Other
B) Which of the above choices do you least prefer?

8) Matchpoints; N-S Vul. You, South, hold:

^ $94 \bullet \mathrm{A} 86 \bullet \mathrm{KJ} 1073$ \& KQ4

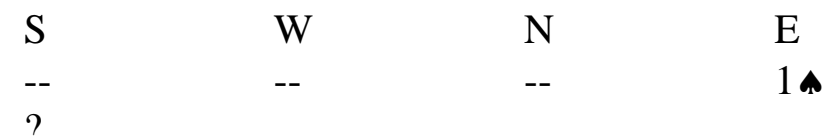
A) Which of the following choices/plans do you prefer?
v) Double
vi) 2 •
vii) Pass, then over (2^), pass, (pass), Double
viii) Pass, then over (2 $\mathbf{\wedge}$ ), pass, (pass), 3
ix) Pass, then over (2 $\uparrow$ ), pass, (pass), Pass
B) Which of the above choices do you regard as the most dangerous? 


\section{Appendix 4}

\section{Brief questionnaire}

Please respond to all questions. You can skip a question if it makes you feel uncomfortable.

Are you generally a person who is fully prepared to take risks or do you try to avoid taking risks?

$\begin{array}{lllllllllllll}\text { (Unwilling to take risks) } & 0 & 1 & 2 & 3 & 4 & 5 & 6 & 7 & 8 & 9 & 10 & \text { (Fully prepared to take risks) }\end{array}$

Age (years):

\begin{tabular}{|c|c|c|c|c|}
\hline$<20$ & $20-30$ & $30-40$ & $40-50$ & $50-60$ \\
\hline $70-80$ & $80-90$ & $90+$ & & \\
\hline
\end{tabular}

Gender/sex: Male Female

What is your marital status?

Single Married Divorced/Separated Widowed

Height:

Over the last five years, approximately what proportion of your assets, apart from residence(s), have been invested in stocks?

$\begin{array}{llllll}\text { Less than } 10 \% & 10-20 \% & 20-30 \% & 30-40 \% & 40-50 \% & 50-60 \% \\ 60-70 \% & 70-80 \% & 80-90 \% & \text { More than } 90 \% & \text { Don't Know } & \end{array}$

Over the last five years, approximately what proportion of your assets, apart from residence(s), have been invested in bonds?

\begin{tabular}{|c|c|c|c|c|}
\hline Less than $10 \%$ & $10-20 \%$ & $20-30 \%$ & $30-40 \%$ & $40-50 \%$ \\
\hline $60-70 \%$ & $70-80 \%$ & $80-90 \%$ & More than $90 \%$ & Don't Know \\
\hline
\end{tabular}

Have you ever started your own company?

$\begin{array}{ll}\text { Yes } & \text { No }\end{array}$

If you smoke cigarettes, on average how many packs of cigarettes do you smoke each month? (enter 0 if nonsmoker)? packs

If you drink alcoholic beverages, on average how many alcoholic drinks do you have each month? (enter 0 if non-drinker)? drinks

How would you describe your sexual orientation?

Heterosexual Homosexual Bisexual Transsexual/Transgender Decline to state 